\title{
Probing crustal and mantle lithosphere origin through Ordovician volcanic rocks along the Iberian passive margin of Gondwana
}

\author{
J. Brendan Murphy ${ }^{\mathrm{a}} *$, G. Gutiérrez-Alonso ${ }^{\mathrm{b}}$, J. Fernández-Suárez ${ }^{\mathrm{c}}$, James A. Braid ${ }^{\mathrm{a}}$ \\ ${ }^{a}$ Department of Earth Sciences, St. Francis Xavier University, Antigonish, Nova Scotia, Canada B2G 2W5 \\ ${ }^{\mathrm{b}}$ Departamento de Geología, Facultad de Ciencias Universidad de Salamanca, 37008 Salamanca, Spain

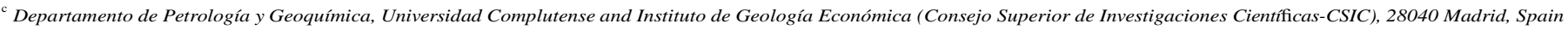

\section{A B S T R A C T}

Northwestern Iberia preserves one of the most complete Paleozoic sequences that document the origin and development of a passive margin along the southern (Gondwanan) flank of the Rheic Ocean. In addition to a well preserved sedimentary record, there is widespread Ordovician volcanic activity that can be used to probe the nature of the lower crust and mantle lithosphere that sourced the volcanic rocks during the Rheic ocean opening. The Ordovician rift-related volcanic sequences provide first-order constraints on the early evolution of the Rheic Ocean. In addition to published and new lithogeochemical data, we provide $\mathrm{Sm} / \mathrm{Nd}$ isotopic data which together constrain the mantle or crustal source and allow an assessment on the role of the basement in Rheic Ocean magmatism. The data imply that the mafic rocks are derived from a variety of sources, including juvenile mantle that was contaminated by sıbduction coeval with Early Ordovician magmatism, suggesting lhe importance $\oint$ arc ativity in morthwest lberia during he opening $\oint$ the Fheic Ocean. Other basalts were derived from a sibcontinental lithospheric mentle hat wæ enriched a about $10 \mathrm{Ga}$. Basalts derived from a mantle enriched at ca. $1.0 \mathrm{Ga}$ occur along aher parts of he Gondwanan margin (Avalonia, Oxaquia) and $\boldsymbol{\Phi}$ he berian basalts nay be aodal representation of a egionally signficant enriched mantle. The Sm-Nd isotopic haracteristics permit a genetic connection between this mantle source ad he basement rocksecently identified in northwest beria. Felsic magmas ae pedominantly intra- crustal magmas derived from melting a Mesoproterozoic crust, lending support to other ines of data that the Gondwanan margin of rorthwest beria wळ predominantly underlain bo a Suth American (Rio Negro) source. Keywords: Rheic Ocean Northwest Iberia Ordovician, Crust Mantle, Sm-Nd isotopes

\section{Introduction}

The Late Cambrian to Early Ordovician evolution of northern Gondwanan margin preserves passive margin sedimentary, intrusive and volcanic sequences that record the origin of the Rheic Ocean and the evolution of its southern flank (e.g. McKerrow and Scotese, 1990; Cocks and Torsvik, 2002). These sequences have been dispersed by the breakup of Pangea and are recorded from Oaxaquia (Mexico) in the west to the Bohemian Massif in the east (Stampfli and Borel, 2002; Keppie et al., 2003; Murphy et al., 2006; Fig. 1). There is general agreement that the origin of the Rheic Ocean was the result of the northward drift of some peri-Gondwanan terranes, such as Avalonia, Carolinia and Ganderia from the Gondwanan margin (McKerrow and

\footnotetext{
* Corresponding author.

E-mail addresses: bmurphy@stfx.ca (J.B. Murphy),gabi@usal.es (G. Gutiérrez-Alonso).
}

Scotese, 1990; Cocks and Fortey, 1990; Cocks and Torsvik, 2002; Stampfli and Borel, 2002; Murphy et al., 2002). However, various models have been proposed in recent years to explain this rifting event (for example van Staal et al., 1998; Crowley et al., 2000; Matte, 2001; Stampfli et al., 2002; von Raumer et al., 2002; Murphy et al., 2006). Northwestern Iberia preserves Late Cambrian-Early Ordovician sedimentary and igneous rocks that provide one of the most complete records of passive margin development along the southern flank of the Rheic Ocean and the effects of its subsequent closure during the Carboniferous Variscan orogeny (for a complete set of references see Gibbons and Moreno, 2002 and Vera, 2004).

A wealth of lithostratigraphic, paleontological and paleomagnetic data have led to a consensus that Iberia was located adjacent to the West African craton during the Early Paleozoic (Fig. 1). Determination of the age and composition of the basement to these sequences is important for understanding the geodynamic evolution and to make palinspastic reconstructions of the northern Gondwanan margin. Until recently, the basement to the passive margin sequence was thought to 



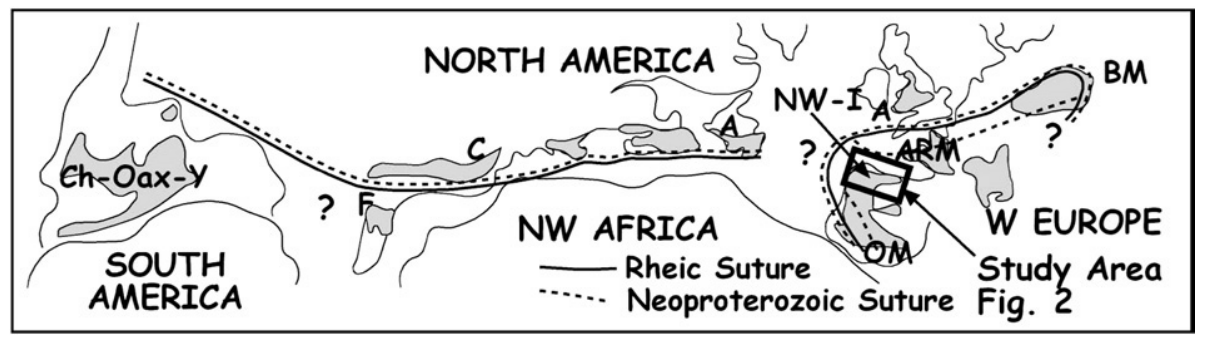

Fig. 1. Localities where the sequences documenting the evolution of northern flank of the Gondwanan margin (southern flank of the Rheic Ocean) are preserved shown in a Pangean reconstruction. Ch-Oax-Y, Chortis-Oaxaquia-Yucatan; F, Florida; C, Carolinia; A, Avalonia; O-M Ossa Morena; NW-I, Northwest Iberia; Arm, Armorica; BM, Bohemian massif.

be part of a Paleoproterozoic (West African) ca 2.0 Ga craton that characterizes the West European Variscan Belt (Guerrot et al., 1989, Samson and D'Lemos, 1998). However, other basement sources in NW Iberia have been identified consisting mainly of Mesoproterozoic (ca. 1.1-1.4 Ga) in addition to some Archaean sources (detrital zircons and white micas, Fernández-Suárez et al., 2000, 2002a,b; Gutiérrez-Alonso et al., 2003, 2005). Also, a recently dated outcrop of presumably basement rocks has yielded a Mesoproterozoic age (Purrido amphi- bolite, $1159 \pm 39$ Ma, U-Pb, zircon, Sánchez-Martínez et al., 2006). However, the Purrido amphibolite is allochthonous relative to the Gondwanan margin. An additional challenge is that the Neoproter- ozoic and Late Paleozoic tectonic events in this region may have involved thrusting of cover sequences relative to their basement. As a result, the relationship between this newly identified basement and the hidden basement that yielded the Ordovician volcanic rocks is unclear. In the Late Neoproterozoic, this region underwent a protracted (ca. 750-550 Ma) low grade tectonothermal evolution during the Cordilleran-type Cadomian orogeny along the northern Gondwanan margin (Gutiérrez-Alonso and Fernández-Suárez, 1996; Fernández- Suárez et al., 1998; Gutiérrez-Alonso et al., 2004; Cuesta et al., 2004; Díaz García, 2006) and Late Cambrian-Early Ordovician extreme stretching (Pérez-Estaún et al., 1990; Martínez-Catalán et al., 1992; Díaz García, 2002; Valverde-Vaquero et al., 2005; Díez Montes, 2006) until the onset of the Rheic ocean lithosphere production. In the Late

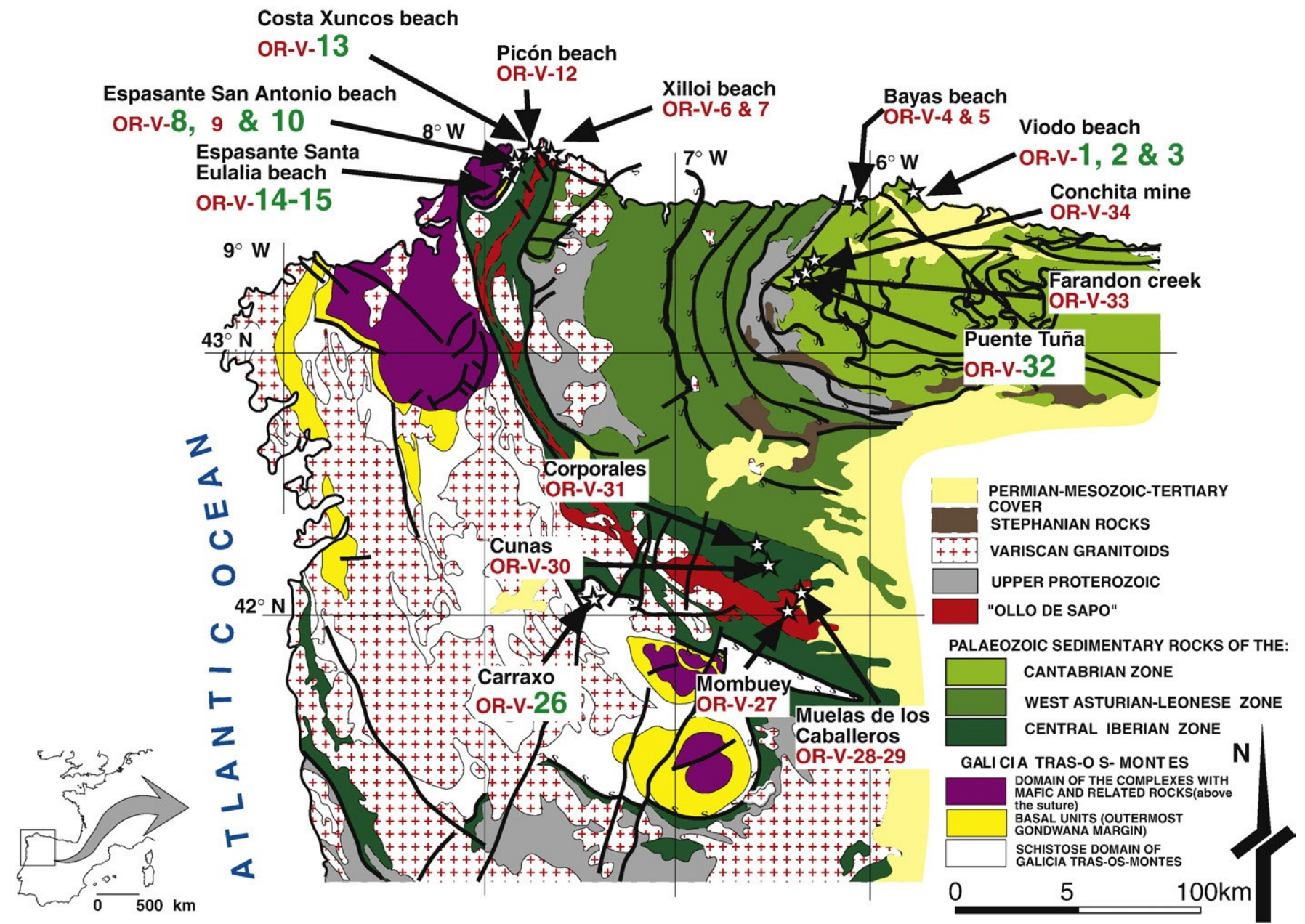

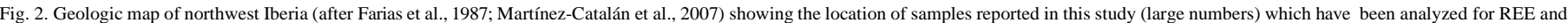
$\mathrm{Sm}-\mathrm{Nd}$ isotopes. More precise locations of samples are given in Table DR-3. 
Paleozoic, collision between Laurussia and Gondwana (Variscan orogeny) is manifest in NW Iberia by significant shortening (including thrusting) and ophiolite obduction, which caused the exposure of part of the Rheic Ocean passive margin basement in the so called Basal Units of the Allochthonous Complexes(Martínez-Catalánetal.,1996)(Fig.2).

The relationship between the inferred and exposed basement and the source or sources of the Ordovician rift-related volcanic sequences would provide first-order constraints on the early evolution of the Rheic Ocean and the nature of the basement and the mantle lithosphere. In addition to a well preserved sedimentary record, there is widespread Ordovician intrusive and volcanic activity, which can be used to probe the nature of the lower crust and mantle lithosphere that provide the source for the volcanic rocks during the Rheic Ocean opening (Murphy et al., 2006).

A focused study on the geochemistry of various igneous rocks exposed in NW Iberia can provide insights into the processes that occurred along this portion of the northern Gondwanan margin. Over the past 20 years, a wealth of geochemical data on the igneous rocks in this region has been published (see Table DR-1) that predominantly focuses on individual tectonostratigraphic zones in the region, and a synthesis of those data is provided here. We also report new geochemical and Sm-Nd isotopic data from representative samples of these igneous rocks, which, together with previously published data, provide constraints on the nature and age of the mantle lithosphere and lower crust at the time of the Rheic Ocean development in northwest Iberia. These data facilitate a comparison between these sources for the various tectonostratigraphic zones in northwest Iberia, an assessment of the degree to which this chemistry may be derived from exposed basement, and an evaluation of their significance in interpreting the evolution of the Rheic Ocean passive margin along the northern margin of Gondwana.

\section{Geological setting}

Although heterogeneously deformed by Late Paleozoic Variscan orogenesis, one of the most complete sections of the northern Gondwanan platform is exposed in northwestern Iberia (Fig. 2) where Paleozoic rocks lie within an intensely curved Variscan orogenic belt (Weil et al., 2001). In addition to preserving record of passive margin development, northwestern Iberia is characterized by several episodes of voluminous volcanic and intrusive igneous activity.

If the Iberian-Armorican Arc is restored to a pre-Variscan geometry (Weil et al., 2001), the Iberian continental platform of Gondwana is shown to be extremely extensive as indicated by its stratigraphic record, classically represented by a thick, mostly siliciclastic sequence that includes the Late Cambrian-Early Ordovi- cian Armorican quartzite, related quartzose clastic rocks and is covered, sometimes as an unconformity by widespread Silurian black shales (Gutiérrez-Marco et al., 1998). These relationships, together with sedimentological studies are consistent with paleogeo- graphic reconstructions which place NW Iberia adjacent to West Africa along the southern flank of the Rheic Ocean during all the Paleozoic (e.g. Martínez-Catalán et al., 2007; Robardet, 2002, 2003).

Paleozoic rocks in the Iberian Massif are divided into zones based on their Lower Paleozoic sedimentary differences, which are inter- preted to reflect their relative proximity to the Gondwanan margin (Fig. 2). The Cantabrian Zone preserves a coastal environment, whereas the West Asturian Leonese, Central Iberian, Galicia Tras-os- Montes (Schistose Domain) and/or Ossa Morena zones preserve the more outboard tectonostratigraphy (Julivert et al., 1972; Quesada, 1990; Ribeiro et al., 1990; Pérez-Estaún et al., 1990; Quesada et al., 1991; Martínez-Catalán et al., 1997, 1999; Marcos and Farias, 1999; Gutiérrez-Marco et al., 1999; Aramburu et al., 2002; Robardet, 2002, 2003; Robardet and Gutiérrez-Marco, 2004). Boundaries between these zones are major Variscan thrusts and reverse faults that are in some cases reactivated by extension in the aftermath of the Variscan orogeny (Martínez-Catalan et al., 1997, 2003).

Lower Ordovician (Tremadoc-Arenigian) volcanism is widespread and is represented in all the paleotectonic zones (Valverde-Vaquero et al., 2005; Díez Montes 2006; Gutiérrez-Alonso et al., 2007). Coeval with this volcanism, ca. $4500 \mathrm{~m}$ of strata accumulated in sub-basins or troughs parallel to the northern Gondwanan margin and are interpreted to reflect a marked increase in subsidence related to tectonic extension and the rift-drift transition stage of Rheic Ocean development (Pérez-Estaún et al., 1990; Martínez-Catalán et al., 1992; Aramburu et al., 2002; Marcos et al., 2004). This extensional event is coeval with the genesis of the widespread Lower Ordovician intrusive granitoid and volcanic rocks which are interpreted as intra-crustal melts generated in response to steep geothermal gradients associated with the rifting event (Ribeiro and Floor, 1987; Gallastegui et al., 1987; Pin et al., 1992; Valverde-Vaquero et al., 2005; Díez Montes, 2006). Although volcanic activity continues until the upper Ordovician, it is relatively scarce and is only locally represented (Heinz et al., 1985, Corretgé and Suárez, 1990, Gallastegui et al., 1992).

The Cantabrian Zone is characterized by voluminous and wide- spread volcanism, and includes several Lower Paleozoic volcanic events that are mostly Lower Ordovician in age although some younger volcanic rocks also occur (Fig. 2; (Loeschke and Zeidler, 1982; Heinz et al., 1985; Gallastegui et al., 1992; Barrero and Corretgé, 2002). Volcanic rocks in the West Asturian Leonese zone (WALZ) are widely distributed but, compared to the Cantabrian Zone are volumetrically minor and their emplacement is thought to have been accompanied by a greater basin subsidence. The northern portion of the Central Iberian Zone (CIZ) preserves the most volumetrically significant Early Ordovician volcanic event in NW Iberia, including the "Ollo de Sapo" belt where voluminous felsic volcanics crop out along a continuous NW- to Ntrending belt (Fig. 2). Detailed studies on the age (са. 495- $480 \mathrm{Ma}$ ) origin and geochemistry of these volcanic rocks can be found in Valverde-Vaquero and Dunning (2000), Castro et al. (1999, 2003), Díez Montes (2006) and Montero et al. (2007). Felsic intrusive bodies in the northern CIZ have U-Pb (zircon) ages ranging from the Late Cambrian-Early Ordovician (Miranda de Douro body, $483 \pm 3$ Ma according to Bea et al., 2006 or $496 \pm 3$ after Zeck et al., 2007) to $465 \pm 10$ Ma (Covelo and San Sebastián bodies; Lancelot et al., 1985). In addition to the "Ollo de Sapo belt", in the southern CIZ, mafic sills with tholeiitic chemistry yield a Sm/Nd isochron age of $436 \pm 17 \mathrm{Ma}$ (López- Moro et al., 2007).

The Schistose Galicia Tras-os-Montes Domain (SGTMD) (Farias et al., 1987; Martínez-Catalán et al., 1996; Marcos et al., 2002) rests tectonically above the CIZ and consists of a thick siliciclastic sequence with interbedded volcanic rocks. Some of the volcanic rocks yield Lower Ordovician (475 \pm 2 Ma, ValverdeVaquero et al., 2005) ages and have been interpreted as the most outboard parts of the passive margin sedimentary wedge of Gondwana.

On top of the most external parts of the Gondwana sedimentary wedge in the Rheic passive margin, the SGTMD, allochthonous complexes consist of (from bottom to top) the Gondwana basement (known as Basal Units, Fig. 2) structurally overlain by two ophiolitic units of Early Ordovician and Devonian age that are interpreted to be the remnants of the Rheic Ocean or subsidiary oceans closed during the Variscan Orogeny(Martínez-Catalán et al., 1997; Arenas et al., 2007a,b). On top of the ophiolites, the upper units are interpreted to be part of the rocks that constitute the northern (Laurussian) margin of the Rheic Ocean (Martínez-Catalán et al.,1997; Arenas etal., 2007a,b).

Underlying the ophiolites, the Basal Units have a continental affinity and are considered to represent the most external part of the Gondwanan margin (Martínez-Catalán et al., 1996). This margin was subducted below the ophiolitic units during the earliest stages of the Variscan Orogeny and was affected by high-pressure and low- to intermediate temperature metamorphism (Arenas et al., 1995; Rodríguez et al., 2003; Rodríguez Aller, 2005). Extensive geochemical 
data on these rocks can be found in (Marquínez, 1984; Arenas, 1988; Díaz García, 1990; Pin et al., 1992; Rodríguez Aller, 2005). Despite their complex tectonothermal history, the igneous protoliths have been found to be Lower Ordovician in age (ca. 480 Ma; Santos Zalduegui et al., 1995 and references therein).

Finally, ophiolites within the allochthonous complexes are pri- marily either Lower Ordovician or Devonian in age (e.g. Arenas et al., 2007a,b). The Lower Ordovician ophiolites occur in several structural slices and may represent the vestiges of the first oceanic crust to be formed in the Rheic Ocean.

\section{Geochemistry}

We combine results from our own samples, with an analysis of geochemical data from the literature to provide an overview of the geochemical and isotopic signatures of the Early Ordovician igneous rocks. The locations of our samples are tabulated (Table DR-3), and their position within the tectonostratigraphic framework of northwest Iberia is shown on a summary map (Fig. 2). In order to facilitate the comparison between rock types, the location of the samples is restored on a schematic cross-section showing their approximate relative positions along the ancient Gondwanan margin (Fig. 3).

\section{Sampling and analytical methods}

In order to deduce the effects of mantle and crustal sources on Ordovician volcanic rocks along the NW Iberian margin of Gondwana, twentytwo samples from various tectonic zones were analyzed for major and trace elements. In the Cantabrian Zone, the oldest volcanic units were sampled (late Cambrian-Early Ordovician Puente Tuña and Farandón volcanics, samples 32 and 33 respectively), as well as the overlying K-bentonites (sample 34) which are of volcanic origin, and yield a Lower Ordovician age (477.5 \pm 1 Ma, U-Pb, zircon; Gutiérrez- Alonso et al., 2007). In addition we sampled volcanic rocks that crop out around the Peñas Cape (Samples 1, 2 and 3, Fig. 2; Suárez et al., 1993). Although there are no precise geochronogical or fossil age constraints, these volcanic rocks are widely interpreted to be Upper Arenig in age (e.g. Gutiérrez-Marco et al., 1999), although they have also been interpreted to be lowermost Upper Ordovician (Dobrotvian, Truyols et al., 1996).

In the northern part of the WALZ, we sampled Middle Ordovician subvolcanic and volcanic rocks within the Luarca Formation (Samples 4 and 5; González Menéndez and Suárez, 2004; Villa et al., 2004) and samples 30 and 31 are representative of the abundant volcanic rocks that crop out in the southern WALZ. There are no published detailed petrologic or geochemical studies available from these rocks. In the CIZ, we present data from several samples taken in the "Ollo de Sapo" region (Samples 6, 7, 27, 28 and 29). In the SGTMD, we selected representative samples of ca. 475 Ma (ValverdeVaquero et al., 2005) volcanic rocks to represent magmatism located at the most outboard part of the para-autochthonous Gondwanan passive margin (Fig. 3; Samples 11,12, 13 and 26).

From the allochthonous complexes, we selected samples from the Basal Units (samples 8 and 10) which have 480 Ma protolith ages and represent the most external part of the Gondwanan margin (Fig. 3; Martínez-Catalán et al., 1996).

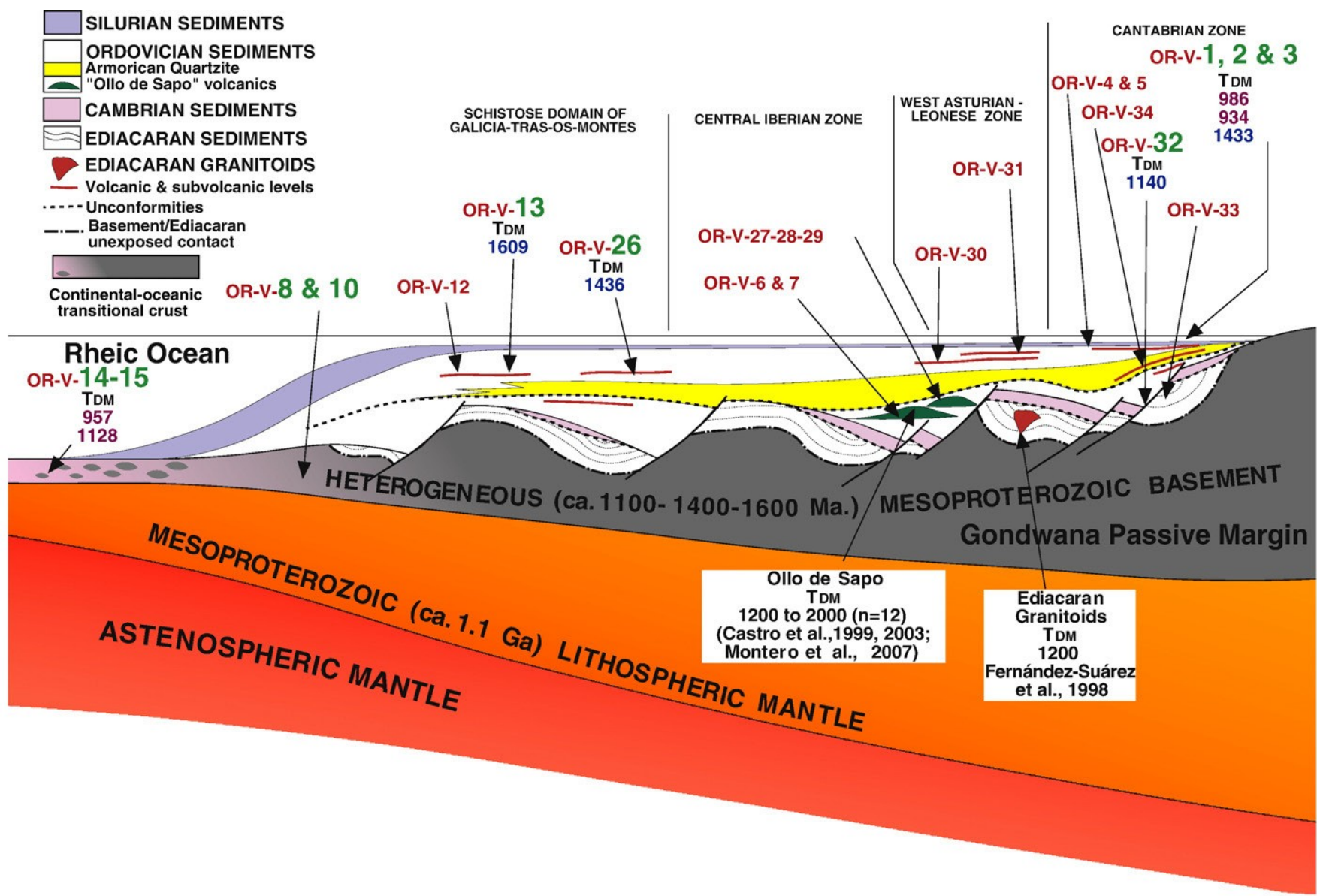

Fig. 3. Location of the analyzed samples restored relative to the northern Gondwanan margin on a schematic cross-section and a summary of the results of our Sm/Nd isotopic data. $T_{\mathrm{DM}}$ for the Ediacaran Granitoids from Fernández-Suárez et al. (1998) and for the Ollo de Sapo belt from Castro et al. (1999, 2003), and Montero et al. (2007). 
Finally, we sampled the Lower Ordovician ophiolites (Samples 14 and 15) from the Moeche unit in the Ortegal Complex. These rocks have an oceanic signature (e.g. Arenas et al., 2007a,b) and correlate with the better known Vila de Cruces ophiolite in the Ordenes Complex, dated at $497 \pm 4 \mathrm{Ma}$, and both are thought to be the remnant of the earliest Rheic Ocean (Arenas et al., 2007a,b).

Details of analytical methods are given in Supplementary File DR-2. Major and trace element (Rb, Sr, Ba, Ga, Zr, Y, Nb, Co, Cu, Pb, Zn, V, Cr and $\mathrm{Ni}$ ) geochemistry was determined by $\mathrm{X}$-ray fluorescence spectro- metry in the Nova Scotia Regional Geochemical Centre at Saint Mary's University, Halifax. Rare earth element and Sm-Nd isotopic analyses were determined by ICP-MS at Memorial University, Newfoundland.
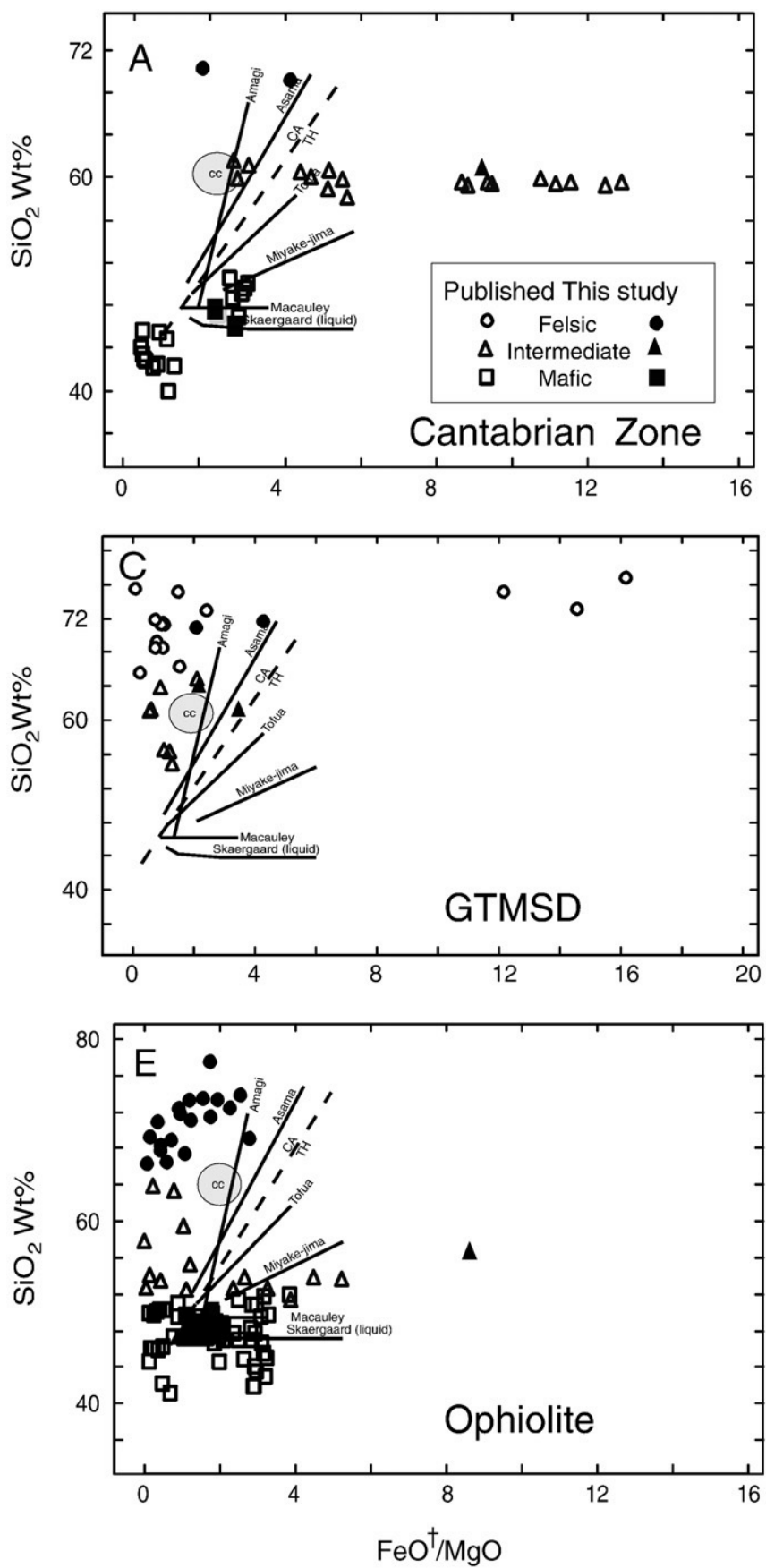

Detailed of analytical methods along with all analyses are in given in Supplementary File DR-2 and all analyses are given in Supplementary File DR-3. Analytical procedures, precision and accuracy are described by Dostal et al. (1986) for the X-ray data, by Jenner et al. (1990) for the REE data and by Kerr et al. (1995) for the Sm-Nd isotopic data.

Three samples, ORV 4 (mafic volcaniclastic), 9 (serpentinite) and 34 (Kbentonite) display anomalous geochemical characteristics and are not plotted on geochemical diagrams. ORV 4 has $26.9 \% \mathrm{SiO}_{2}$ very high iron oxide and alumina (38.8 and $19.1 \mathrm{wt} . \%$, respectively) and is clearly highly altered. The probable cumulate nature of the protolith to the serpentinite is indicated by its very high $\mathrm{MgO}$ (36.5 wt.\%) and $\mathrm{Cr}$ (N 2000 ppm) and low Zr (b 5 ppm). Extensive alteration of the K-
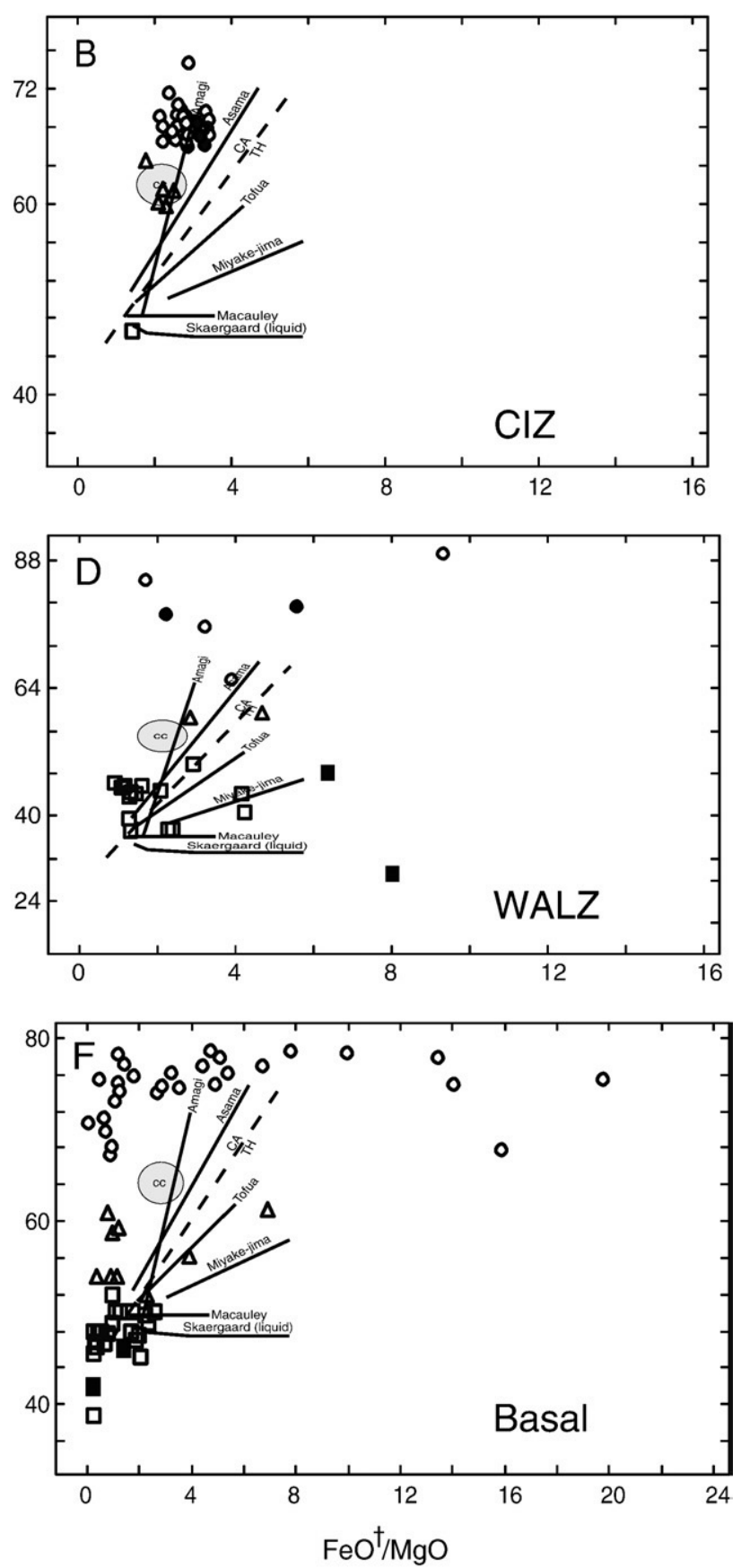

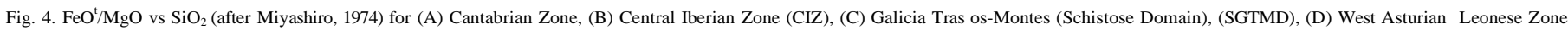

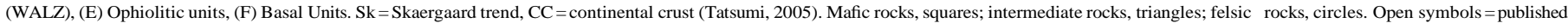
data; filled symbols, our data. 

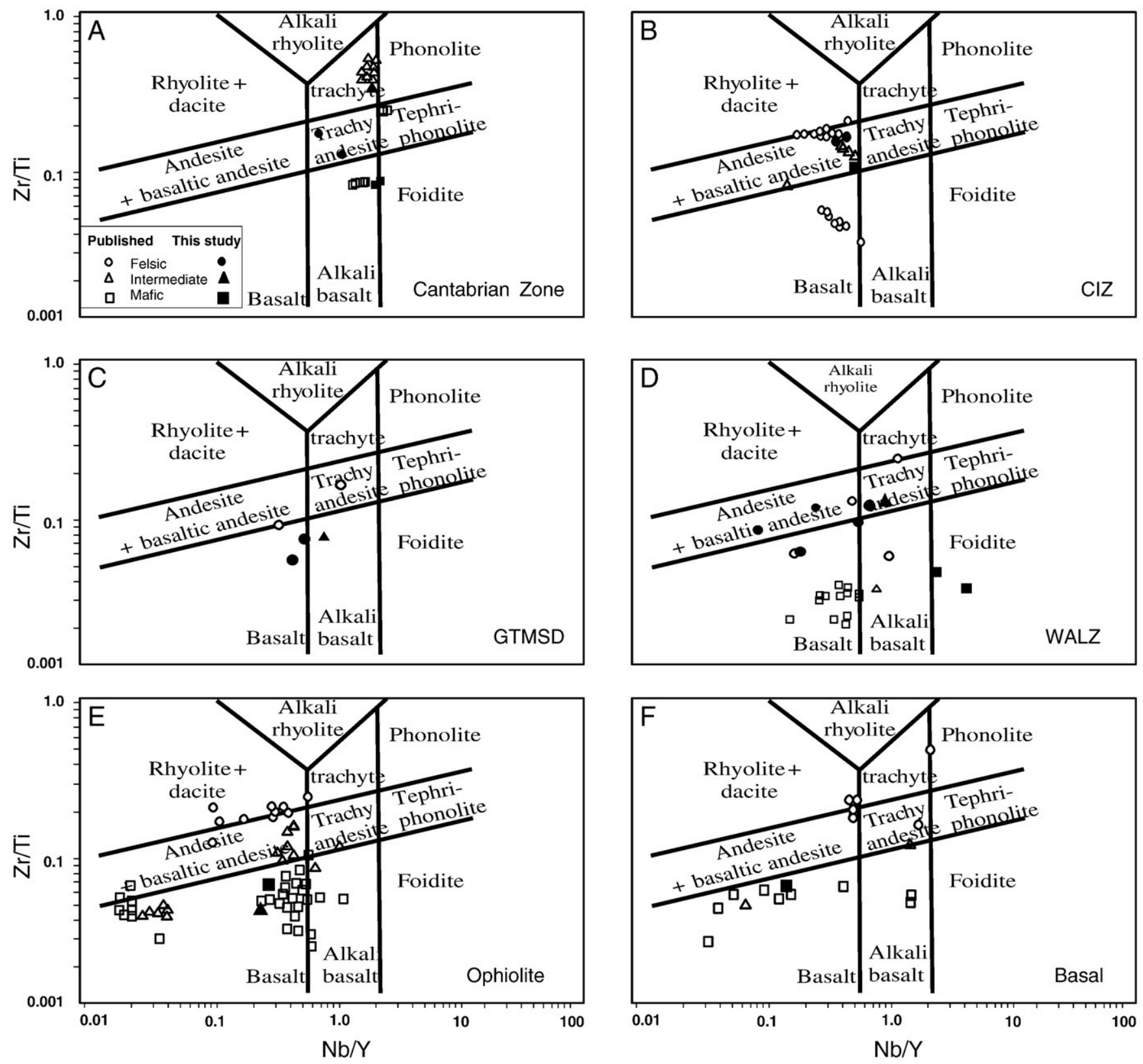

Fig. 5. Zr/Ti vs Nb/Y discrimination diagram (after Winchester and Floyd, 1977; Pearce, 1996) for mafic rocks (A) Cantabrian Zone, (B) Central Iberian Zone (CIZ), (C) Galicia Tras os- Montes (Schistose Domain), (SGTMD), (D) West Asturian Leonese Zone (WALZ), (E) Ophiolitic units, (F) Basal Units. Open symbols=published data; filled symbols, our data.

bentonite is indicated by its very high $\mathrm{Al}_{2} \mathrm{O}_{3}$ (37.1wt.\%). The remaining 19 samples were selected for REE analysis and 11 of those were selected for Sm-Nd isotopic analysis. The entire lithogeochemical and isotopic dataset and details on the analytical methods are available on-line (Supplementary FileDR-2).

A wealth of geochemical data on the igneous rocks of this region (Table DR-1) has been published over the past twenty years. However, many of these data sets do not include a full complement of trace element analyses required to probe the nature of their mantle or crustal sources. In addition, they have been produced by different analytical methods using different standards and analytical proce- dures that have evolved over this time period. Nevertheless, the data are consistent enough to provide a broad overview and some first- order constraints and a summary of these data are shown in Figs. 4 to 7. For comparative purpose, we also show our data on these plots and we categorize and organize them and their description from the described paleogeographic zones.

\section{Results}

The complex tectonic evolution of this region has resulted in secondary processes, as evidenced by the high loss on ignition (LOI) in several samples, which have affected the primary concentrations of many major and several trace elements. This alteration has obscured many of the primary igneous trends. As a result, we describe the major element abundances only in very general terms, and we focus on the abundances of trace elements such as high field strength (HFS) and rare earth (REE) elements, which are both considered to be "relatively" immobile during hydrous alteration (e.g. Winchester and Floyd, 1977; Pearce, 1996). 

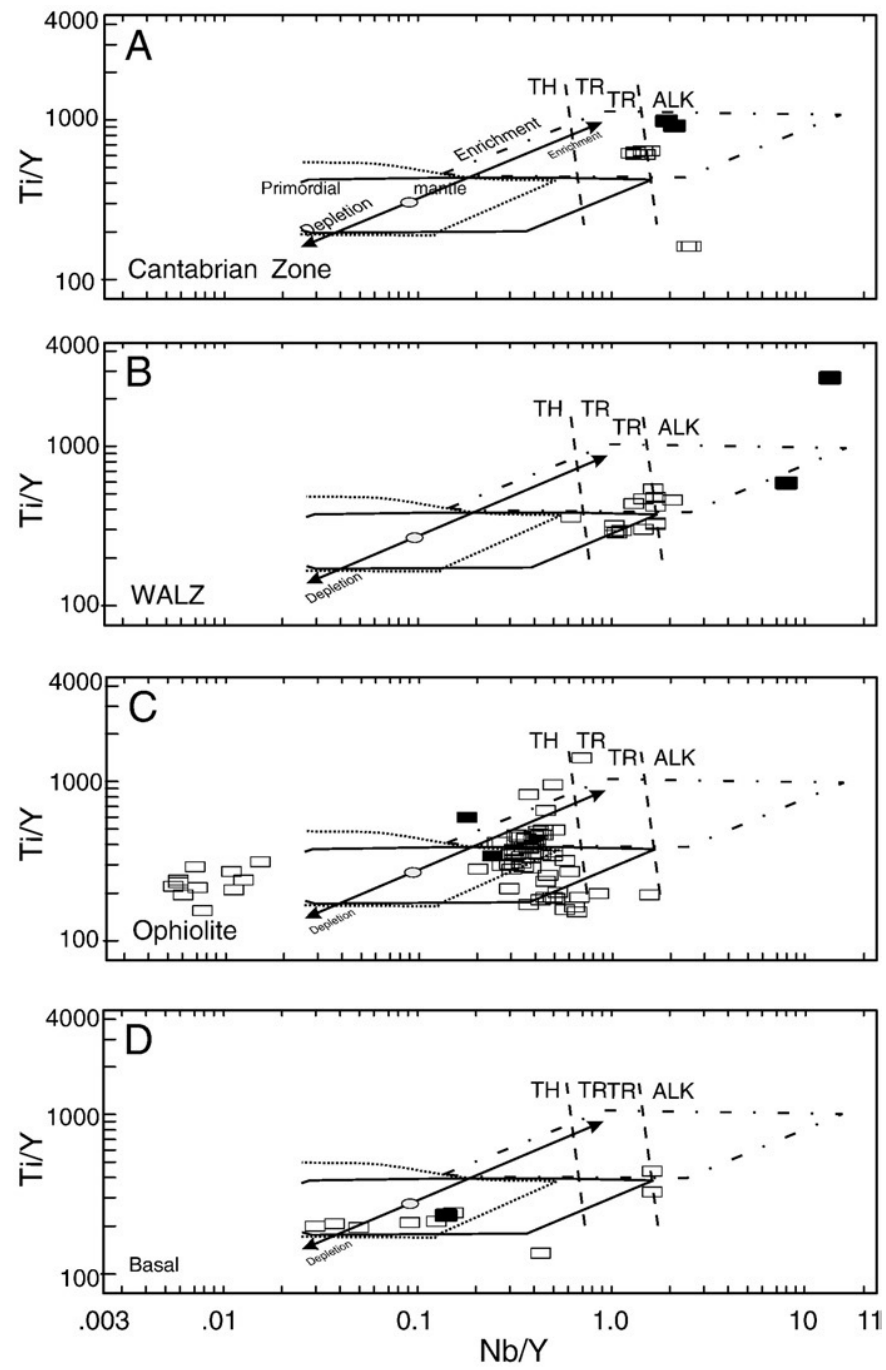

Fig. 6. Ti/Y vs Nb/Y discrimination diagram (after Pearce, 1982, 1996) for mafic rocks (A) Cantabrian zone, (B) Ophiolitic units, (C) West Asturian Leonese Zone (WALZ), (D) Basal Unit. Open symbols = published data; filled symbols, our data. CIZ and WALZ are not included in this plot because of the lack of mafic rocks in these zones.

The Cantabrian Zone volcanic rocks are bimodal, with a gap in $\mathrm{SiO}_{2}$ from about 52 to $60 \mathrm{wt} . \%$. Both mafic and intermediate rocks have a wide range in $\mathrm{FeO}^{\mathrm{t}} / \mathrm{MgO}$ which may, in part, be due to secondary alteration. Felsic rocks have $\mathrm{FeO}^{\mathrm{t}}$ and $\mathrm{FeO}^{\mathrm{t}} / \mathrm{MgO}$ that straddle the calc- alkalic tholeiitic boundary (Fig. 4A). The $\mathrm{Zr} / \mathrm{Ti}$ vs. Nb/Y plot (Fig. 5) is a proxy for the total alkalies vs. silica classification diagram, where $\mathrm{Nb} / \mathrm{Y}$ measures the degree of alkalinity and $\mathrm{Zr} / \mathrm{Ti}$ is an index of fractionation (Winchester and Floyd, 1977; Pearce, 1996). Cantabrian zone mafic volcanic rocks are characterized by high $\mathrm{Nb} / \mathrm{Y}$ (Fig. $5 \mathrm{~A}$ ), varying from alkalic basalt-foidite to tephri-phonolite in composition. The alkalic affinity of the mafic rocks is also indicated on the $\mathrm{Ti} / \mathrm{Y} \mathrm{vs} \mathrm{Nb} / \mathrm{Y}$ plot (Fig. 6A) whereas the high $\mathrm{Zr} / \mathrm{Y}$, Ti and $\mathrm{Zr}$ are typical of within plate volcanic rocks (Fig. 7A).

The CIZ and the Galicia Schistose Zone are dominated by

values similar to those of the average continental crust but on average are richer in $\mathrm{SiO}_{2}$ (Fig. 4B, C). The majority of the samples plot in the calkalkalic field of Miyashiro (1974).

Basalts from the WALZ show a wide range in $\mathrm{FeO}^{\mathrm{t}} / \mathrm{MgO}$ (Fig. 4D) and similar ranges in $\mathrm{Nb} / \mathrm{Y}$ and $\mathrm{Zr} / \mathrm{Ti}$ to the basalts of the Cantabrian Zone (Fig. $5 \mathrm{~B})$. Their high $\mathrm{Nb} / \mathrm{Y}$ is typical of transitional to alkalic basalts (Figs. 5B, 6B) and the high $\mathrm{Zr} / \mathrm{Y}$ is typical of within plate basalts (Fig. 7B). Mafic rocks from the ophiolite bodies also have a wide range in $\mathrm{FeO}^{\mathrm{t}} / \mathrm{MgO}$ (Fig. 4E) and appear to be composed of two different suites. Although they contain similar $\mathrm{Zr} / \mathrm{Ti}$, one suite has very low $\mathrm{Nb} /$ $\mathrm{Y}$ (b 0.02) and a relatively narrow range in Ti/Y (c. 150-350) and is subalkalic (Figs. 5C, 6C). The other suite has much higher $\mathrm{Nb} / \mathrm{Y}(0.3$ to 2.0) and a wider range in Ti/Y (c. 150-1000) and their compositions straddle the subalkalic-transitional-alkalic boundaries. These differences are highlighted on the $\mathrm{Zr} / \mathrm{Y}$ vs $\mathrm{Zr}$ diagram (after Pearce and Norry, 1979) in which the subalkalic rocks plot in the island arc basalt field, whereas subalkalic-alkalic rocks plot as within plate basalts (Fig. 7B). The subalkalic rocks have characteristics similar to the coeval Vila de Cruces ophiolite. Recent data from this ophiolite indicate that its geochemical signature is typical of island arc tholeiite and the ophiolite is interpreted to have been generated in a back arc basin (Arenas et al., 2007a).

\section{Mafic rocks}

Mafic rocks analyzed in this study facilitate a comparison between the Cantabrian Zone (ORV 1,2), the Central Iberian Zone (ORV 7) of the inner Gondwanan margin and mafic rocks of the Basal Units (the probable Gondwanan basement; ORV 8, 10) and the ophiolites from the Galicia Tras-os-Montes (ORV 14, 15) of the outer margin (Fig. 3). ORV1,2 areEarly Ordovicianbasalts characterizedbyhigh $\mathrm{FeO}^{\mathrm{t}}, \mathrm{TiO}_{2}$, and $\mathrm{FeO}^{\mathrm{t}} / \mathrm{MgO}$. On $\mathrm{Zr}-\mathrm{Ti}-\mathrm{Y}$ discrimination diagrams, they plot in the within plate field, and according to the high $\mathrm{Nb} / \mathrm{Y}$, they are clearly alkalic (Figs. 4 to 7). Thus their chemistry is broadly similar to previously published data from the Cantabrian Zone. On $\mathrm{Ta} / \mathrm{Yb}$ vs $\mathrm{Ce} /$ $\mathrm{Yb}$ and $\mathrm{Th} / \mathrm{Yb}$ diagrams, they plot just above the enriched mantle array suggesting only minor crustal contamination (Fig. 8A,B). This same characteristic is also evident on the Th-Hf-Ta diagram (Fig. 8C) and is consistent with their high $\mathrm{Nb} / \mathrm{Y}$ (1.25 and 1.3, respectively). They display strong LREE enrichment, with high $\mathrm{La} / \mathrm{Yb}_{\mathrm{n}} \sim 20-30$, which, together with the high $\mathrm{Nb} / \mathrm{Y}$, suggests derivation from a garnet lherzolite mantle (Fig. 9A). Trace element abundances are more enriched than typical EMORB, and spidergram plots show that they most closely resemble basalts derived from an OIB-type mantle source (Fig. 9B). The basalts display no Nb-Ta anomaly (Fig. 10), consistent with other evidence for lack of contamination either by crustal or subduction components. These characteristics are broadly similar to coeval rocks in the Ossa Morena Zone described by Sánchez-García et al. (2003). ORV 1 and 2 have very similar Sm-Nd isotopic characteristics with $\varepsilon_{\mathrm{Nd}}(t=500)$ values of +1.0 and +1.1 , respectively and $T_{\mathrm{DM}}$ values of ca. 0.93 to $0.99 \mathrm{Ga}$ (Fig. 11A, Table 1). The lack of trace element evidence for crustal contamination suggests that these values reflect derivation from a mantle source that was enriched in LREE and Nd relative to Sm at about $1.0 \mathrm{Ga}$. Similar trace element and $\mathrm{Sm}-\mathrm{Nd}$ isotopic characteristics have been identified in other regions that were located along the northern margin of Gondwana at that time (e.g. Acatlan Complex of Oaxaquia, Mexico and the Antigonish Highlands of Nova Scotia; Murphy and Dostal, 2007, 2008).

Sample ORV 7 is a rare example of a mafic volcanic rock within CIZ (Ollo de Sapo zone). This sample has significantly lower $\mathrm{TiO}_{2}, \mathrm{Zr}, \mathrm{P}_{2} \mathrm{O}_{5}$, $\mathrm{Nb} / \mathrm{Y}$ and higher $\mathrm{Zr} / \mathrm{P}_{2} \mathrm{O}_{5}$ than the Cantabrian Zone mafic rocks, features consistent with subalkalic tholeiitic rocks. However, on Ti-Y-Zr diagrams (Figs. 6, 7), the sample plots in the arc field and the influence of a subduction or crustal component is also indicated on Th-Hf-Ta and $\mathrm{Ta} / \mathrm{Yb}$ vs $\mathrm{Ce} / \mathrm{Yb}$ and $\mathrm{Th} / \mathrm{Yb}$ plots. ORV 7 has LREE enrichment, a intermediate to felsic rocks. Many of the samples have $\mathrm{FeO}^{\mathrm{t}} / \mathrm{MgO}$ On spidergrams (Fig. 9A, B), ORV 7 has a pronounced Nb-Ta anomaly, typical of subduction or crustal influence.

The difference in the geochemical and isotopic signatures of mafic rocks (Gondwanan basement and ophiolite) that were located along the outer margin of Gondwana apparent from the analysis of the previously published data (Figs. 5 to 7) is clearly visible in our data. prono unced Eu anom aly and mode rate LRE E enric hmen $\mathrm{t}$ (La/Y $\mathrm{b}_{\mathrm{n}} \sim$ 10). 

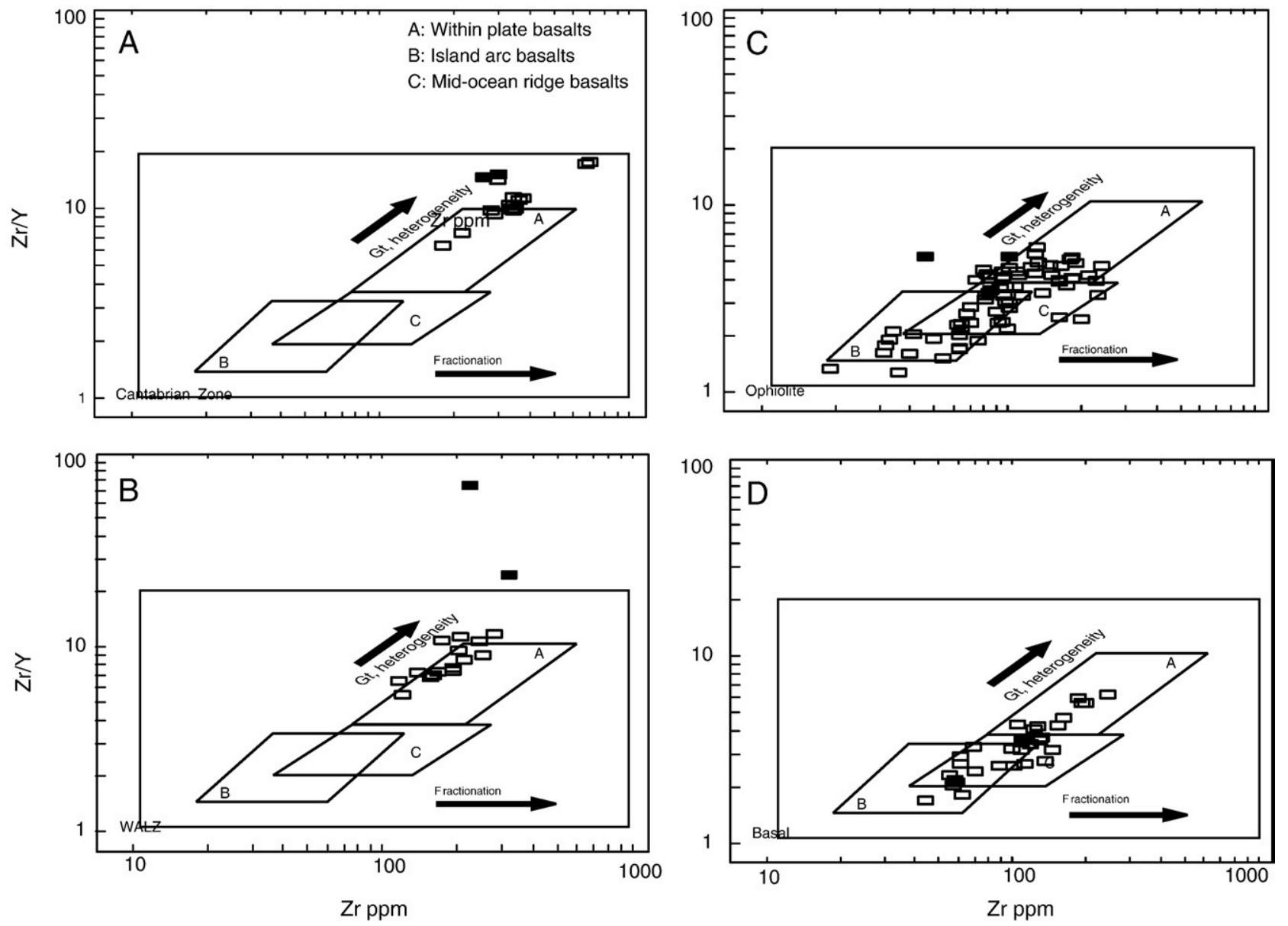

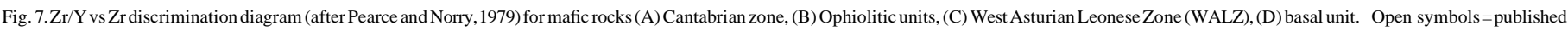
data; filled symbols, our data. CIZ and WALZ are not included in this plot because of the lack of mafic rocks in these zones.

Gondwanan basement (ORV 8 and 10) and ophiolitic (ORV 14 and 15) mafic rocks plot in two distinct fields both of which are different from mafic rocks from the inner margin. Sample ORV 10 has low $\mathrm{TiO}_{2}$, $\mathrm{Zr}$, and $\mathrm{P}_{2} \mathrm{O}_{5}$, elevated $\mathrm{Zr} / \mathrm{P}_{2} \mathrm{O}_{5}$, and low $\mathrm{Nb} / \mathrm{Y}$, features consistent with relatively undifferentiated subalkalic tholeiitic rocks. On Ti-Y-Zr plots, ORV-10 plots in the field of overlap between MORB and WPB (Figs. 6, 7). ORV 8 is intermediate in composition with $\mathrm{SiO} 2$ of $64.1 \mathrm{wt}$.\%. Trace element plots such as $\mathrm{Ta} / \mathrm{Yb}$ vs $\mathrm{Ce} / \mathrm{Yb}$ and $\mathrm{Th} / \mathrm{Yb}$ and $\mathrm{Th}-\mathrm{Hf}-\mathrm{Ta}$ show that these rocks are probably generated by partial melting of a depleted mantle with only minor influence of either subduction or crustal components (Fig. 8A-C). ORV 8 and 10 have flat NMORB-like profiles with slight LREE depletion (Fig. 10A,B) and ORV-8 has a pronounced Eu anomaly. The negative $\mathrm{Nb}$ anomaly exhibited by ORV-8 relative to NMORB (Fig. 10B) identifies contamination by a subduction zone component that is not apparent on the other plots. Both samples have a Sm/Nd ratio similar to CHUR, are characterized by high ${ }^{147} \mathrm{Sm} /{ }^{144} \mathrm{Nd}\left(0.196\right.$ and 0.205 , respectively) and by $\varepsilon_{\mathrm{Nd}}$ values are similar to those of depleted mantle suggesting that both samples were derived from a juvenile mantle source. Although the high ${ }^{147} \mathrm{Sm} /{ }^{144} \mathrm{Nd}$ precludes a meaningful calculation of $T_{\mathrm{DM}}$, the similarity of the $\varepsilon_{\mathrm{Nd}}$ values to that of depleted mantle suggests that the $T_{\mathrm{DM}}$ age is similar to its crystallization age. The isotopic data also indicate that the contamination by subduction exhibited by ORV-8 probably occurred at about the same time as magma generation, consistent with published geochemical data that many of the ophiolites were formed in a suprasubduction zone environment (e.g. Arenas et al., 2007a, and references therein).

Samples ORV 14 and 15 are from the lower ophiolite unit (Moeche Unit, equivalent to the better known Vila de Cruces Unit) which is interpreted to be a vestige of Ordovician oceanic crust from the Rheic Ocean (Arenas et al., 2007a,b). Trace element diagrams (Fig. 8A-C) indicate that these rocks contain high $\mathrm{Ta} / \mathrm{Yb}$ and $\mathrm{Ta} / \mathrm{Hf}$ that are typical of an enriched mantle. However, the rocks also do not plot along the mantle array indicating that they have been contaminated by either a subduction or crustal component. ORV 14 shows moderate LREE enrichment $\left(\mathrm{La} / \mathrm{Yb}_{\mathrm{n}} \sim 6.5\right)$ whereas ORV 15 has lower $\Sigma$ REE, more subdued LREE enrichment $\left(\mathrm{La} / \mathrm{Yb}_{\mathrm{n}} \sim 2.5\right)$ and flat HREE $\mathrm{Gd} / \mathrm{Lu}_{n} \sim 0.8-1.2$ (Fig. 10A). Trace element abundances most closely resemble basalts derived from an enriched mantle source although Th enrichment and $\mathrm{Nb}$ depletion are consistent with other plots suggesting contamina- tion. (Fig. 10C). Their Sm-Nd characteristics are similar to one another, although these characteristics are very different from ORV 8 and 10.

They have much lower $\varepsilon_{\mathrm{Nd}}(t=500)$ values of +2.2 and +2.6 , much lower ${ }^{147} \mathrm{Sm} /{ }^{144} \mathrm{Nd}$ (0.141 and 0.157 , respectively) and $T_{\mathrm{DM}}$ values of ca.0.96 to $1.1 \mathrm{Ga}$. Given the evidence for contamination, the geological meaning of these $T_{\mathrm{DM}}$ ages is uncertain. Although the data plot close to calculated assimilationfractional crystallization curves between depleted mantle and typical upper crust (Fig. 11B and C), their apparent similarity with crustal values would imply a high percentage of assimilation that is not evident in other geochemical features. Alternatively, these values could reflect a combination of influences including derivation from an enriched subcontinental lithospheric mantle (similar to the source of ORV 1 and 2) and contamination either by Mesoproterozoic crust or by a crust enriched in LIL by fluids derived from a subduction zone.

Taken together, these data indicate mafic complexes located along the Gondwanan margin in Ordovician times are isotopically 

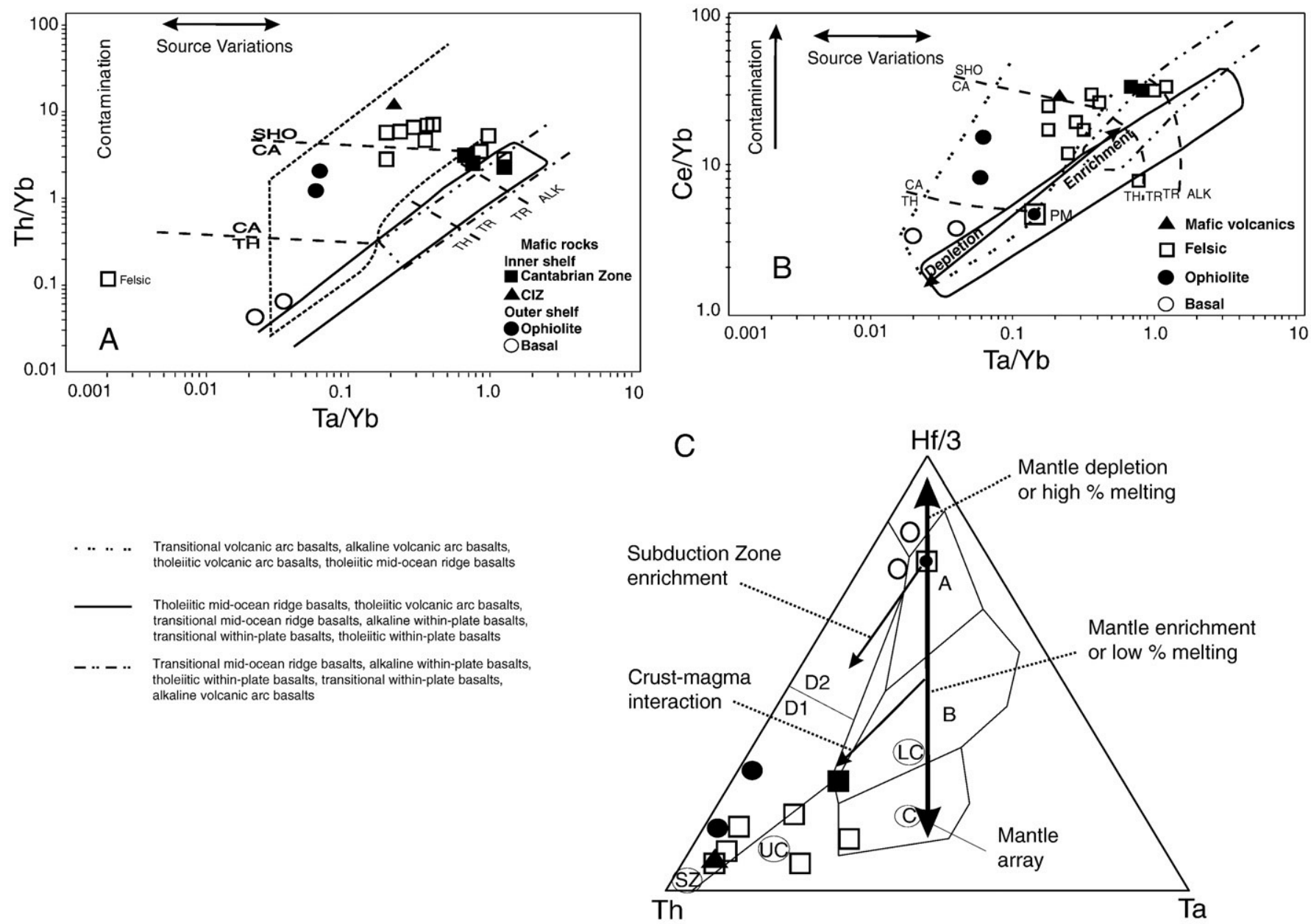

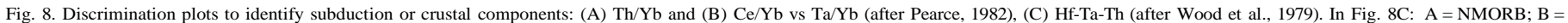

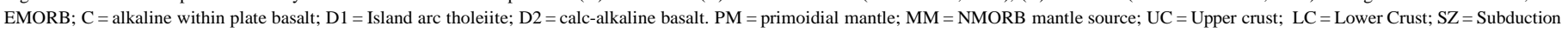
Component.

heterogeneous. Gondwanan basement complexes have compositions typical of juvenile depleted mantle at 480 Ma that was affected by coeval subduction. Ophiolite samples, on the other hand, have compositions typical of derivation from an enriched mantle.

\section{Felsic rocks}

A geochemical comparison between the felsic rocks of various tectonostratigraphic zones offers the opportunity to characterize the sources of crustally-derived melts along this portion of the Gondwa- nan margin. Most felsic rocks from the Cantabrian Zone (3, 30, 32), the SGTMD (12, 13, 26) and CIZ $(27,28,29,31)$ display very similar major element chemistry and are characterized by $\mathrm{FeO}$ and $\mathrm{FeO} / \mathrm{MgO}$ that plot either in the calc-alkalic field or straddle the calc-alkalic- tholeiitic boundary line (Fig. 3). There is no obvious geochemical or isotopic distinction between the felsic rocks of these various tectonostratigraphic zones, and for simplicity of presentation, they are grouped together on geochemical and isotopic plots. They have a wide range in $\mathrm{Nb} / \mathrm{Y}$ and $\mathrm{Zr} / \mathrm{Ti}$ ratios, and straddle intermediate to felsic compositions and the alkalic-subalkalic boundary (Figs. 4-6). Other than ORV 30 and 33, which have elevated $\mathrm{Nb}, \mathrm{Y}, \mathrm{Ta}$ and $\mathrm{Yb}$ values that are typical of within plate granites, most samples plot in the Volcanic Arc Granite field (Fig. 12A,B), suggesting either an origin in an ensialic arc, or recycling of older crust that was itself formed in an arc environment.
With the exception of ORV 33, the felsic samples display moderate LREE enrichment (Fig. 13A), a moderate to pronounced Eu anomaly (Eu* $\sim 0.1$ to 0.6$)$ and flat HREE profiles $\left(\mathrm{Gd} / \mathrm{Yb}_{\mathrm{n}} \mathrm{Yb}_{n}\right.$

1.5). On an NMORB-normalized plot, all rocks display a pronounced negative Nb anomaly (Fig. 13B). Such REE and spidergram profiles are typical of crustal melts that have undergone plagioclase fractionation. The overall compositional similarity to upper continental crustal (UCC) rocks is shown on the UCC normalized plot (Fig. 13C). Sample ORV 33, a trachyte, has very high $\Sigma$ REE, $\mathrm{La} / \mathrm{Yb}_{\mathrm{n}}$ of 12.5 , and $\mathrm{Gd} / \mathrm{Yb}_{\mathrm{n}}=3.5$ and high $\mathrm{Nb}$ and Ta (Figs. 12, 13) and REE profiles typical of felsic rocks generated by fractional crystallization from a more mafic magma.

Geochemical analyses of CIZ (Montero et al., 2007) shows very similar characteristics to the dominant features described above. These rocks have $\mathrm{Nb}-\mathrm{Ta}-\mathrm{Yb}$ and REE abundances that are indis- tinguishable from those shown in Figs. 12 and 13.

Sm-Nd analyses of the felsic rocks display more negative $\varepsilon_{\mathrm{Nd}}(t=500)$ values than the mafic rocks $(-1.1$ to -5.6$)$. Plots of $\varepsilon_{\mathrm{Nd}}$ versus normalized $\mathrm{Nb} / \mathrm{La}$ and ${ }^{147} \mathrm{Sm} /{ }^{144} \mathrm{Nd}$ (Fig. 11B,C) show that the felsic

rocks have isotopic and trace element characteristics that are distinct from the mafic rocks and support other geochemical evidence that they are not derived from the mafic rocks by fractionation or assi- milation fractionation mechanisms. Although one sample (ORV 32) has similar $T_{\mathrm{DM}}(1.1 \mathrm{Ga})$ to spatially-related mafic rocks (ORV 1 and 2) in the Cantabrian Zone (Figs. 2 and 3 ), it has significantly lower $\varepsilon_{\mathrm{Nd}}$. 
A

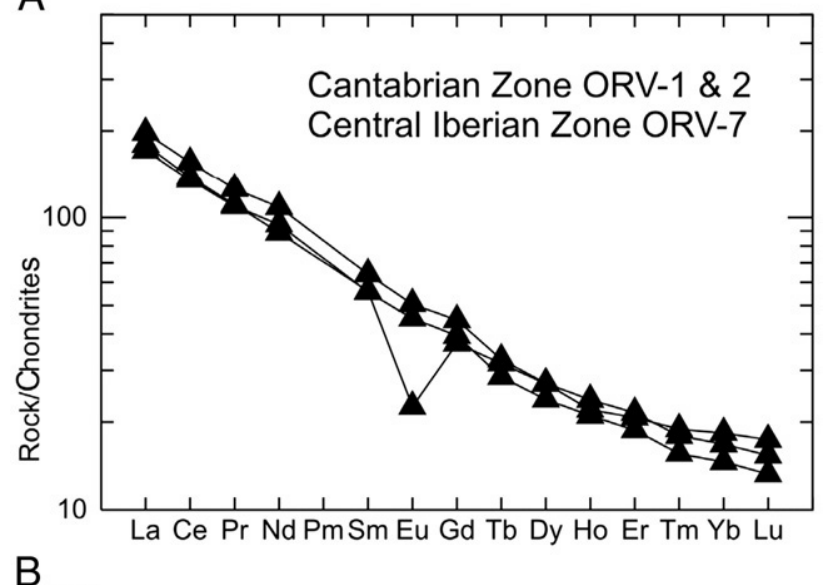

B

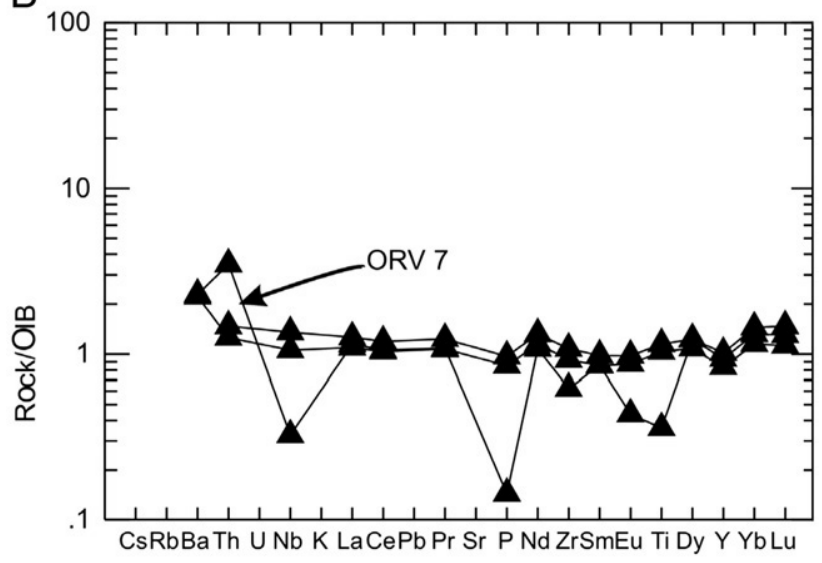

Fig. 9. REE and trace element values of Cantabrian Zone mafic rocks normalized to (A) chondrite, (B) Ocean Island Basalts. Normalizing values from Sun and McDonough (1989).

Although a lithospheric mantle component cannot be ruled out for this sample, these characteristics together with their overall geo- chemical similarity with the composition of the upper continental crust (Fig. 13C) indicate that the sample is dominated by a component derived from a source rock with lower $\mathrm{Sm} / \mathrm{Nd}$ values that are more typical of crustal rocks. The low $\varepsilon_{\mathrm{Nd}}$ and the high $T_{\mathrm{DM}}$ of the other felsic samples ranges from 1.43 to 1.61 Ga suggesting that these rocks are crustal melts primarily derived from a Mesoproterozoic crustal basement. Therefore, the apparent arc affinity evident in Fig. 12 could have been inherited from an older continental crust that was itself formed in an arc environment. In comparison to typical Avalonian crust, the $\varepsilon_{\mathrm{Nd}}$ values are lower and the $T_{\mathrm{DM}}$ ages are older.

Comparable Sm-Nd isotopic results have been obtained from the CIZ by Castro et al. (1999, 2003) and Montero et al. (2007). These samples have $\varepsilon_{\mathrm{Nd}}(t=500)$ ranging from -2.4 to -5.0 , and eleven of twelve samples have $T_{\mathrm{DM}}$ ranging from 1.2 to $1.8 \mathrm{Ga}$, and the remaining sample has a $T_{\mathrm{DM}}$ of $2.2 \mathrm{Ga}$.

\section{Summary and discussion}

Geochemical and isotopic analyses indicate that Ordovician mafic rocks in NW Iberia are derived from variable mantle sources in- cluding ophiolites with mafic volcanics derived from a subcontinental lithospheric mantle and a juvenile mantle basement that was contaminated by a subduction component at the time of magma generation. This mixed signature is consistent with a transitional oceanic-continental crustal setting proximal to the northern Gondwanan margin.
Some of the analyzed samples are typical of rift-related basalts derived from garnet lherzolite mantle, with little or no chemical modification due to subduction or crustal contamination. These features are compatible with their proposed genetic relationship to the opening of the Rheic Ocean (Martínez-Catalán et al., 1997; van Staal et al., 1998; Murphy et al., 2006; Arenas et al., 2007a,b). The calculated $T_{\mathrm{DM}}$ ages, however, are significantly older than that of the Late Cambrian-Early Ordovician opening of the Rheic (or Iapetus) Oceans. These ages are interpreted to reflect derivation from a subcontinental lithospheric mantle that was heterogeneously meta- somatized, probably at ca. 1.0 to $1.1 \mathrm{Ga}$. Such features have also been interpreted in the mantle lithosphere beneath Avalonia, the terrane
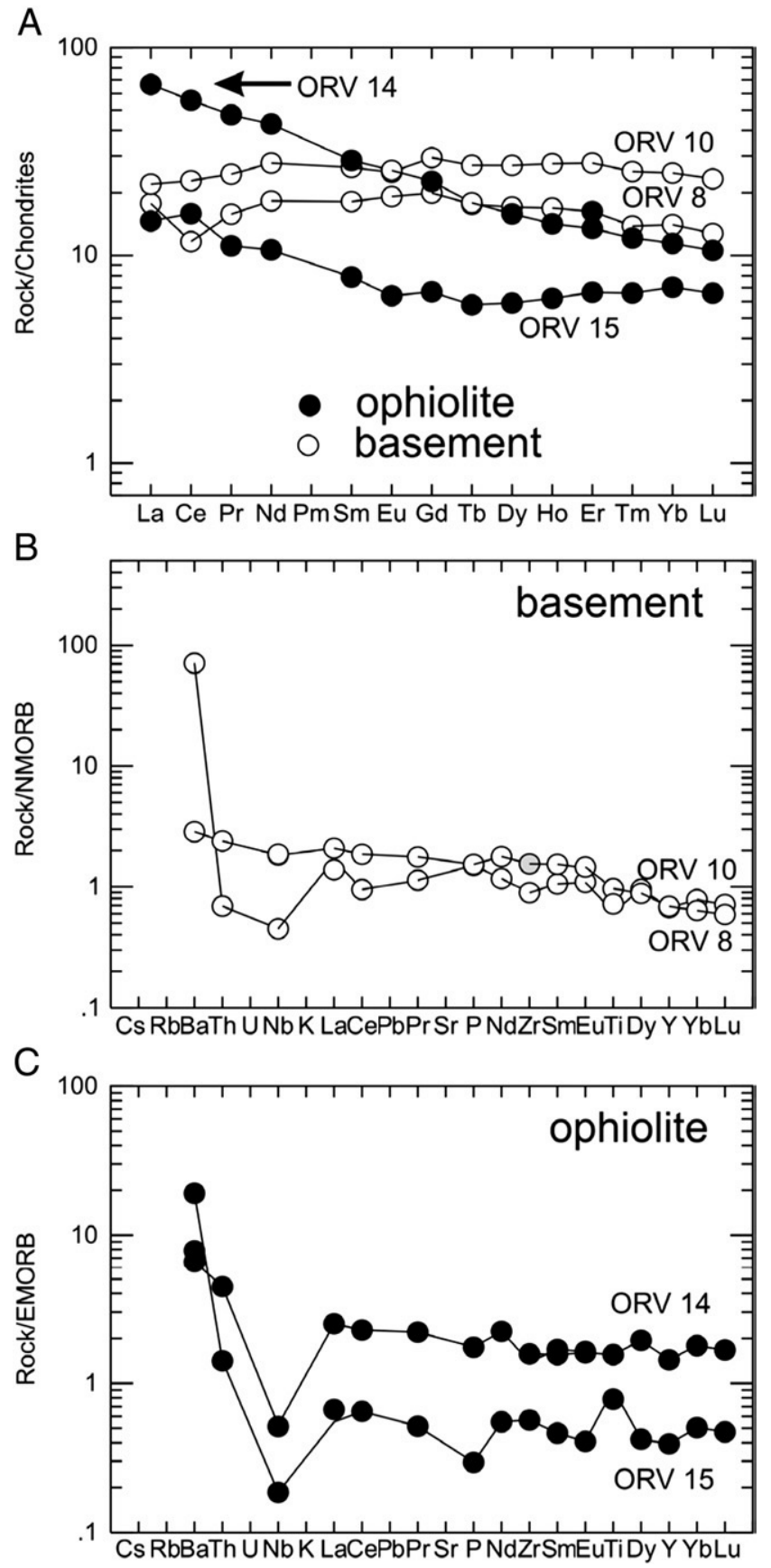

Fig. 10. REE and trace element values of ophiolitic rocks normalized to (A) chondrite. ORV 8 and 10 are shown normalized to NMORB (B), whereas ORV 14 and 15 are show normalized to EMORB (C). Normalizing values from Sun and McDonough (1989). 

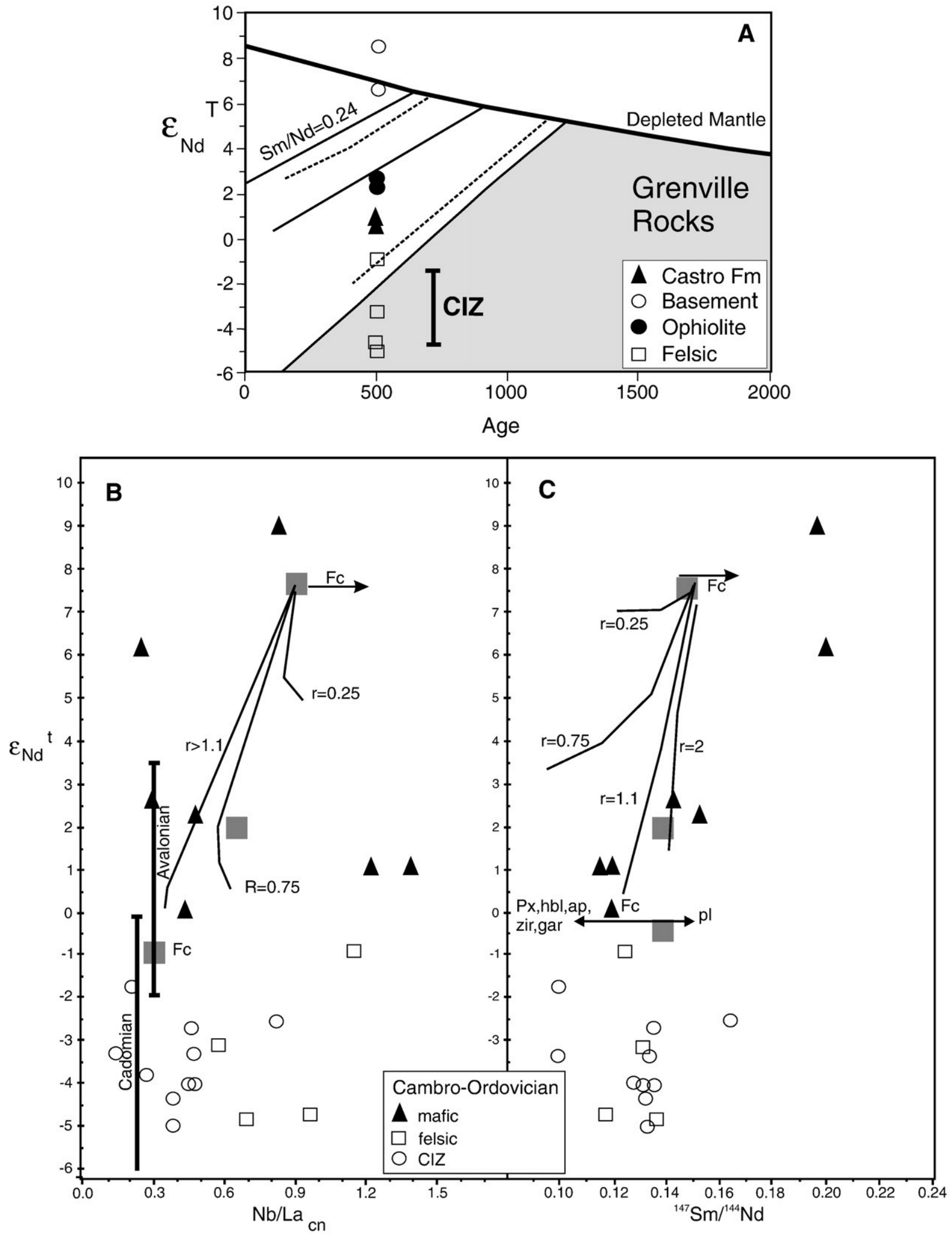

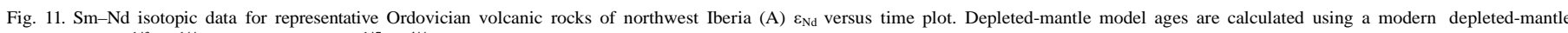

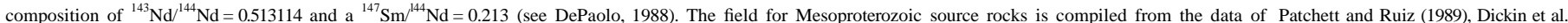

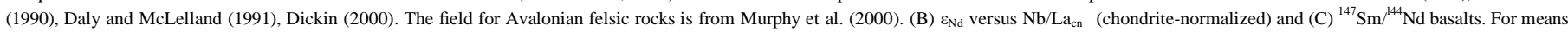

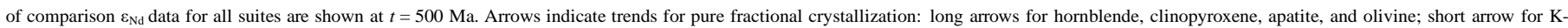
feldspar. Curves indicate assimilation-fractional crystallization (AFC; DePaolo, 1988) trends for

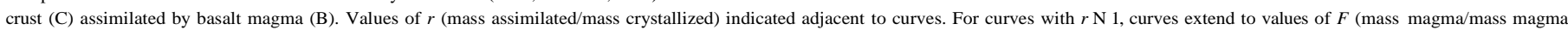
initial) $\sim 4$, whereas for curves where $r b 1$, curves end at $F \sim 0.1$. Data for CIZ from Montero et al. (2007). 
Sm-Nd Isotopic data for Ordovician igneous rocks formed along the Iberian passive margin of Gondwana

\begin{tabular}{|c|c|c|c|c|c|c|c|c|c|}
\hline & $\mathrm{Nd}(\mathrm{ppm})$ & $\mathrm{Sm}(\mathrm{ppm})$ & ${ }^{147} \mathrm{Sm} /{ }^{144} \mathrm{~N} \pi$ & ${ }^{143} \mathrm{~N} /{ }^{144} \mathrm{~N} / \mathrm{d}$ & $2 \sigma$ & $\varepsilon(0)$ & $\varepsilon(500)$ & $T(\mathrm{DM})$ & \\
\hline \multicolumn{10}{|c|}{ Cantabrian Zone } \\
\hline ORV 1 & 39.65 & 7.87 & 0.1200 & 0.512440 & 5 & -3.9 & 1.0 & 986 & Mafic \\
\hline ORV 2 & 46.40 & 9.04 & 0.1177 & 0.51 & 4 & -3.9 & 1.1 & 934 & Mafic \\
\hline \multicolumn{10}{|l|}{ Felsic } \\
\hline ORV 3 & 18.43 & 3.57 & 0.1170 & 0.51 & 7 & -10.3 & -5.2 & 1433 & Rhyolite \\
\hline ORV 13 & 21.22 & 4.67 & 0.1329 & 0.51 & 5 & -9.2 & -5.1 & 1609 & Rhyolite \\
\hline ORV 26 & 29.82 & 6.41 & 0.1300 & 0.51 & 4 & -7.9 & -3.7 & 1436 & Rhyolite \\
\hline ORV 32 & 56.12 & 11.35 & 0.1223 & 0.51 & 5 & -5.9 & -1.1 & 1140 & Rhyolite \\
\hline \multicolumn{10}{|c|}{ Gondwanan basement } \\
\hline ORV 8 & 8.29 & 2.82 & 0.21 & 0.51 & 4 & 6.9 & 6.4 & - & Amphibolite \\
\hline ORV 10 & 11.96 & 3.88 & 0.2 & 0.51 & 4 & 8.7 & 8.7 & - & Mafic \\
\hline \multicolumn{10}{|l|}{ Ophiolite } \\
\hline ORV 14 & 18.8 & 4.4 & 0.14 & 0.51 & 5 & -0.9 & 2.6 & 957 & Ophiolite \\
\hline ORV 15 & 5.210 & 1.350 & 0.16 & 0.51 & 5 & -0.3 & 2.2 & 1128 & Ophiolite \\
\hline
\end{tabular}

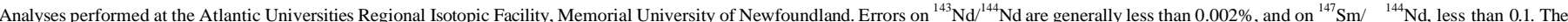

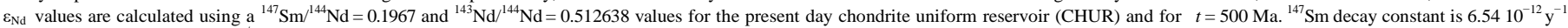

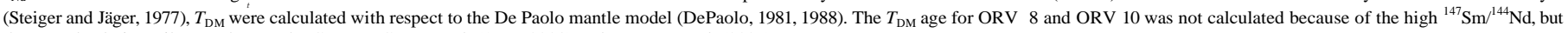
they are clearly juvenile. For data on the CIZ, see Castro et al. (1999, 2003) and Montero et al. (2007)

which probably migrated away from the Gondwanan margin when the Rheic Ocean formed and beneath Oaxaquia which remained along the Gondwanan margin (Murphy et al., 2006; Murphy and Dostal, 2007). The data are also compatible with a mantle source similar to that which yielded the Mesoproterozoic (1.159 \pm 39 Ma, Purrido Unit) metagabbro exposed in NW Iberia (Sánchez-Martínez et al., 2006). If

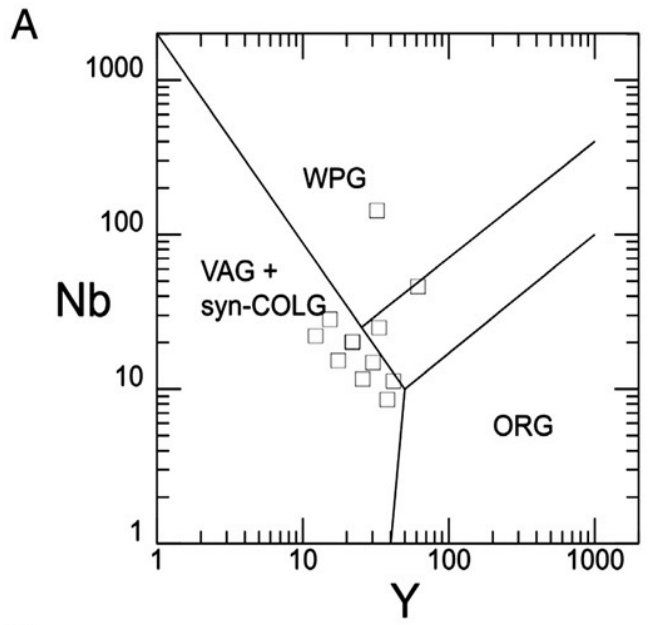

B

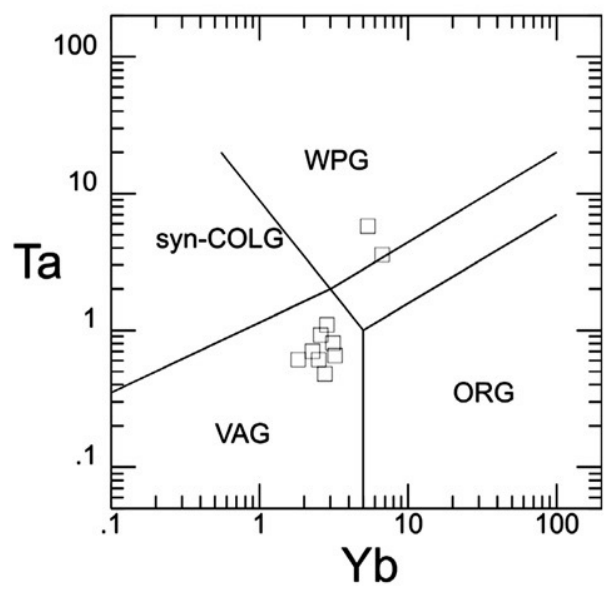

so, the younger (e.g. $0.95 \mathrm{Ga}$ ) $T_{\mathrm{DM}}$ ages of some of the mafic samples can be attributed to a minor juvenile component.

Some of the felsic rocks are alkalic, and are probably related to the within plate basalts by fractionation. The remaining felsic rocks, with flat HREE, negative $\varepsilon_{\mathrm{Nd}}$ isotopic values and $T_{\mathrm{DM}}$ ages between 1.1 and

1.6 Ga are probably crustal melts, suggesting derivation from Mesoproterozoic crust. These $T_{\mathrm{DM}}$ ages are older than those of Avalonian lower crust (e.g. Murphy et al., 2000). Sánchez-Martínez et al. (2006) identified a $1.6 \mathrm{Ga}$ inherited component in Purrido amphibolite, and it is possible that these model ages reflect that Mesoproterozoic component. Mesoproterozoic basement is also atypical of the West African Craton and is more typical of a South American affinity. The presence of a Mesoproterozoic lower crustal basement in NW Iberia is compatible with the interpretation of Gutiérrez-Alonso et al. (2005) for detrital mica data from Early Paleozoic platformal rocks in the NW Iberia which indicate proximity to Mesoproterozoic South American (Rio Negro) basement. These authors attribute the presence of Mesoproterozoic basement in this region to strike-slip transport along the northern Gondwanan margin of a sliver of South American crust into the West African realm during the Ediacarin-Early Cambrian(Fernández-Suárezetal.,2000,2002a,b; Gutiérrez-Alonso et al., 2003, 2005).

Taken together, these data suggest that the lower crust in NW Iberia included a significant Mesoproterozoic (ca. 1.4-1.6 Ga) compo- nent which overlay a ca. 1.0-1.1 Ga subcontinental mantle lithosphere in Early Ordovician times. This geometry had a significant influence on the geochemistry of the basalts that erupted during the opening of the Rheic Ocean. The data also indicate the juxtaposition of older crust above younger mantle lithosphere by Late Cambrian-Early Ordovician times. The origin of this relationship requires further study. It may reflect an allochthonous relationship between the Rio Negro crust and the underlying mantle that was generated before, during or final delivery of the Rio Negro crust into the West African realm. Alternatively, it may reflect a delamination event between crust and mantle in the Neoproterozoic, i.e. prior to transportation from the South American to the West African realm.

\section{Acknowledgements}

We thank two anonymous reviewers for their constructive com- ments. JBM acknowledges the generous support and hospitality of the Universidad de Salamanca during a sabbatical in 2005, and the continuing support of N.S.E.R.C. (Canada) through Discovery and Research Capacity Development grants. G.G.-A. funding comes from Spanish Education and Science Ministry Project GrantCGL2006-00902 

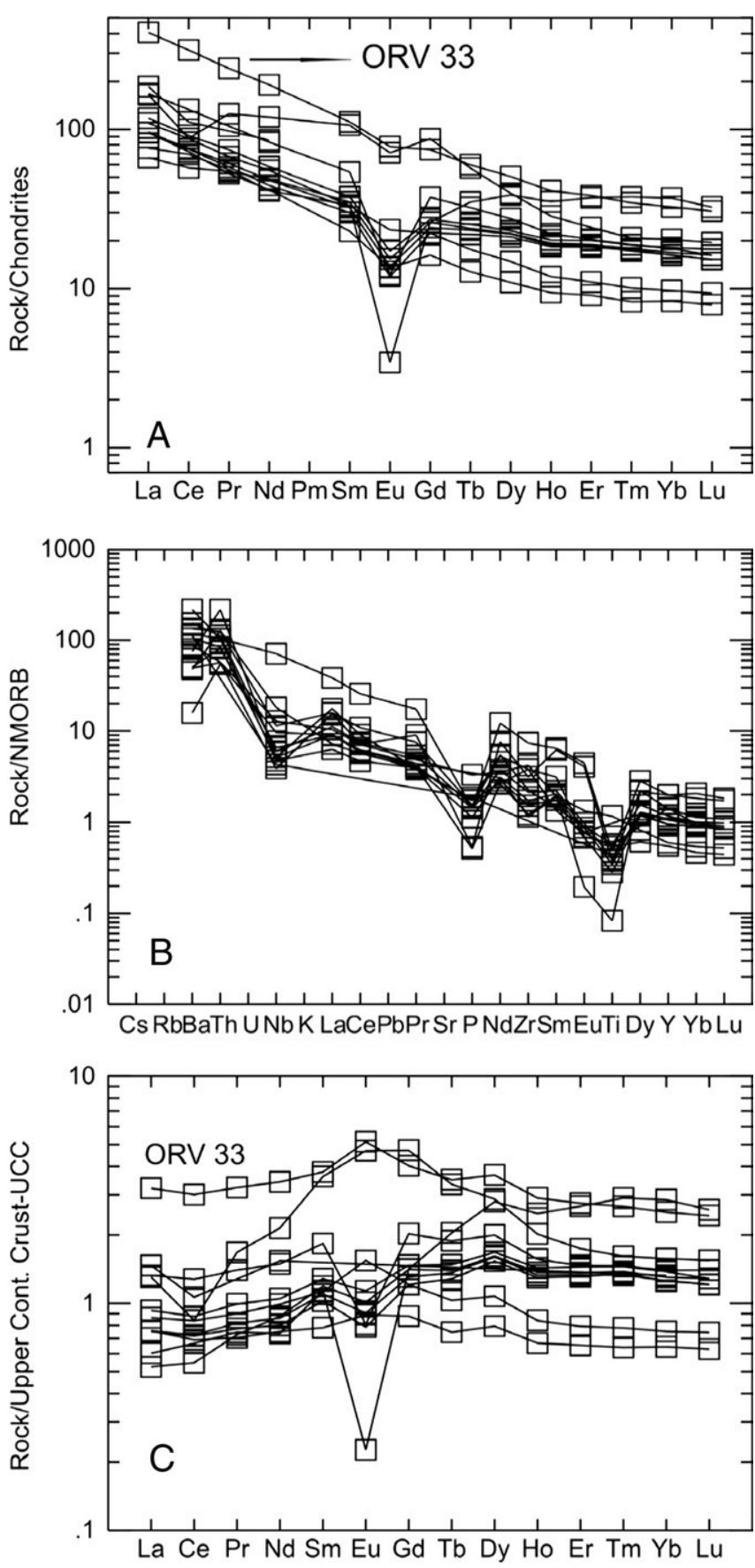

Fig. 13. REE and trace element abundances for the felsic rocks normalized to (A) chondrite (values after Sun and McDonough, 1989), (B) NMORB (values after Sun and McDonough, 1989) and (C) Upper Continental Crust (values after Taylor and McLennan, 1985).

(O.D.R.E.) and the Mobility Program Grant PR2007-0475. JAB is funded through an N.S.E.R.C. Post-Graduate scholarship.

\section{Appendix A. Supplementary data}

Supplementary data associated with this article can be found, in the online version, at doi:10.1016/j.tecto.2008.03.013.

\section{References}

Aramburu, C., Truyols, J., Arbizu, M., Méndez Bedia, I., Zamarreño, I., García-Ramos, J.C., Suárez de Centi, C., Valenzuela, M., 2002. El Paleozoico Inferior de la Zona Cantábrica. In: El Paleozoico Inferior de Ibero-América. In: Rabano, I., Gutiérrez-Marco, J.C., Saavedra, J. (Eds.), Universidad de Extremadura, pp. 397-421 (in Spanish).
Arenas, R., 1988. Evolución petrológica y geoquímica de la Unidad Alóctona inferior del Complejo Metamórfico Básico-Ultrabásico de Cabo Ortegal (Unidad de Moeche) y del Silúrico paraautóctono, Cadena Hercínica Ibérica (NW de España). Corpus Geologicum Gallecieae 4 543 p. (in Spanish).

Arenas, R., Rubio Pascual, F.J., Díaz García, F., Martínez Catalán, J.R., 1995. High-pressure microinclusions and development of an inverted metamorphic gradient in the Santiago Schists (Ordenes Complex, NW Iberian Massif, Spain): evidence of subduction and syn-collisional decompression. Journal of Metamorphic Geology 13, 141-164.

Arenas, R., Martínez Catalán, J.R., Sánchez Martínez, S., Fernández-Suárez, J., Andonae- gui, P. Pearce, J.A., Corfu, F., 2007a. The Vila de Cruces Ophiolite: a remnant of the early Rheic Ocean in the Variscan suture of Galicia (Northwest Iberian Massif). Journal of Geology 115, 129148.

Arenas, R., Martínez Catalán, J.R., Sánchez Martínez, S., Díaz García, F., Abati, J., Fernández- Suárez, J. Andonaegui, P., Gómez-Barreiro, J., 2007b. Paleozoic ophiolites in the Variscan suture of Galicia (northwest Spain). In: HatcherJr. Jr., R.D., Carlson, M.P., McBride, J.H., Martínez Catalán, J.R. (Eds.), 4-D Framework of Continental Crust. Geological Society Memoir, vol. 200, pp. 425444

Barrero, M., Corretgé, L.G., 2002. La diferenciación petrográfica y geoquímica de las rocas ígneas del Arroyo Farandón (Asturias). Geogaceta 32, 135-138 (in Spanish).

Bea, F., Montero, P., Talavera, C., Zinger, T., 2006. A revised Ordovician age for the oldest magmatism of Central Iberia: U-Pb ion-microprobe and LA-ICPMS dating of the Miranda do Douro orthogneiss. Geologica Acta 4, 395-401.

Castro, A., Patiño Douce, A.E., Corretge, L.G., de la Rosa, J.D., El-Biad, M., El-Hmidi, H., 1999. Origin of peraluminous granites and granodiorites, Iberian massif, Spain: an experimental test of granite petrogenesis. Contributions to Mineralogy and Petrology 135, 255-276.

Castro, A., Corretge, L.G., de la Rosa, J.D., Fernández, C., López, S., García-Moreno, O., Chacón, H., 2003. The Appinite-Migmatite Complex of Sanabria, NW Iberian Massif, Spain. Journal of Petrology 44, 1309-1344.

Cocks, L.R.M. Fortey, R.A., 1990. Biogeography of Ordovician and Silurian faunas. In: McKerrow, W.S., Scotese, C.R. (Eds.), Paleozoic Paleogeography and Biogeography. Geological Society Memoir, vol. 12, pp. 97-104.

Cocks, L.R.M., Torsvik, T.H., 2002. Earth geography from 500 to 400 million years ago: a faunal and palaeomagnetic review. Journal of the Geological Society of London 159, 631-644.

Corretgé, L.G., Suárez, O., 1990. Igneous rocks of the Cantabrian and Palentian Zones. In: Dallmeyer, R.D., Martínez-García, E. (Eds.), Pre-Mesozoic geology of Iberia. Springer-Verlag, Berlin, pp. $115-128$.

Crowley, Q.G., Floyd, P.A., Winchester, J.A., Franke, W., Holland, J.G., 2000. Early Palaeozoic rift-related magmatism in Variscan Europe: fragmentation of the Armorican Terrane Assemblage. Terra Nova 12, 171-180.

Cuesta, A., Gallastegui, G., Suárez, O., Rubio Ordoñez, A., 2004. Magmatismo neoproterozoico calcoalcalino en el Antiforme del Nancea (N de España). Geogaceta 36, 15-18 (in Spanish).

Daly, J.S., McLelland, J.M., 1991. Juvenile middle Proterozoic crust in the Adirondack Highlands, Grenville Province, northeastern North America. Geology 19, 119-122.

DePaolo, D.J., 1988. Neodymium Isotope Geochemistry: An Introduction. Springer Verlag, New York. 187p

Díaz García, F., 1990. La geología del sector occidental del Complejo de Órdenes (Cordillera hercínica, NW de España). Terra Nova 3, 269 (in Sapnish).

Díaz García, F., 2002. Tectónica y magmatismo Ordovícicos en el área de Sanabria, Macizo Ibérico. Geogaceta 32, 119-122 (in Sapnish).

Díaz García, F., 2006. Geometry and regional significance of Neoproterozoic (Cadomian) structures of the Narcea Antiform, NW Spain. Journal of the Geological Society, London 163, 499508

Dickin, A.P., 2000. Crustal formation in the Grenville province: Nd isotopic evidence. Canadian Journal of Earth Sciences 37,165-181.

Dickin, A.P., McNutt, R.H., Clifford, P.M., 1990. A neodymium isotope study of plutons near the Grenville Front in Ontario, Canada. Chemical Geology 83, 315-324.

Díez Montes, A. 2006. La geología del Dominio “Ollo de Sapo" en las comarcas de Sanabria y Terra do Bolo. PhD Thesis, University of Salamanca, Spain, 496 pp.(in Spanish)

Dostal, J., Baragar, W.R.A., Dupuy, C., 1986. Petrogenesis of the Natkusiak continental basalts, Victoria Island, N.W.T. Canadian Journal of Earth Sciences 23, 622-632.

Farias, P., Gallastegui, G., González-Lodeiro, F., Marquínez, J., Martín Parra, L., Martínez Catalán, J.R., De Pablo Maciá, J.G., Rodríguez Fernández, L.R., 1987. Aportaciones al conocimiento de la litoestratigrafía y estructura de Galicia Central. Faculdade de Ciências do Porto. Memorias do Museu e Laboratório Mineralógico e Geológico 1, 411-431 (in Spanish).

Fernández-Suárez, J., Gutiérrez-Alonso, G., Jenner, G.A., Jackson, S.E., 1998. Geochronol- ogy and geochemistry of the Pola de Allande granitoids (northern Spain). Their bearing on the Cadomian/Avalonian evolution of NW Iberia. Canadian Journal of Earth Sciences 35, 1439 1453.

Fernández-Suárez, J., Gutiérrez-Alonso, G., Jenner, G.A., Tubrett, M.N., 2000. New ideas on the Proterozoic-Early Paleozoic evolution of NW Iberia: insights from U-Pb detrital zircon ages. Precambrian Research 102, 185-206. doi:10.1016/S0301-9268 (00)00065-6.

Fernández-Suárez, J., Gutiérrez-Alonso, G., Cox, R., Jenner, G.A., 2002a. Assembly of the Armorica microplate: a strike-slip terrane delivery? Evidence from U-Pb ages of detrital zircons. Journal of Geology 110, 619-626. doi:10.1086/341760.

Fernández-Suárez, J., Gutiérrez-Alonso, G., Jeffries, T.E., 2002b. The importance of along margin terrane transport in Northern Gondwana: insights from detrital zircon parentage in Neoproterozoic rocks from Iberia and Brittany. Earth and Planetary Science Letters 204, 75-88. doi:10.1016/S0012-821X(02)00963-9.

Gallastegui, G., Martín Parra, L.M., Pablo Maciá, J.G., de. Rodríguez Fernández, L.R., 1987. Las metavulcanitas del Dominio Esquistoso de Galicia tras os Montes: petrografía, 
geoquímica y ambiente geotectónico (Galicia, NO de España). Cuadernos do Laboratorio Xeoloxico de Laxe, Coruña 15, 127-139 (in Spanish).

Gallastegui, G., Aramburu, C., Barba, P., Fernández, L.P., Cuesta, A., 1992. El vulcanismo del Paleozoico Inferior de la Zona Cantábrica (NO de España). In: Rabano, I., Gutiérrez- Marco, J.C., Saavedra, J. (Eds.), El Paleozoico Inferior de Ibero-América. Universidad de Extremadura, pp. 435-452 (in Spanish).

Gibbons, W., Moreno, M.T. (Eds.), 2002. The Geology of Spain. The Geological Society. London. 649 pp.

González Menéndez, L., Suárez, O., 2004. Caracterización petrológica y geoquímica de los diques basálticos de Cadavedo (Valdés, Asturias). Trabajos de Geología, Universidad de Oviedo 24, 81-89 (in Spanish).

Guerrot, C., Peucat, J.J., Capdevila, R., Dosso, L., 1989. Archean protoliths within Early Proterozoic granulitic crus of the west European Hercynian belt: possible relics of the West African craton. Geology 17, 241-244.

Gutiérrez-Alonso, G., Fernández-Suárez, J., 1996. Geología y Geoquímica del granitoide pre-varisco de Puente de Selce (Antiforme del Narcea, Asturias). Revista de la Sociedad Geológica de España 9, 227-239 (in Spanish)

Gutiérrez-Alonso, G., Fernández-Suárez, J., Jeffries, T.E., Jenner, G.E., Tubrett, M.N., Cox, R., Jackson S.E., 2003. Terrane accretion and dispersal in the northern Gondwana margin: an Early Paleozoic analogue of a long lived active margin. Tectonophysics 365, 221-232. doi:10.1016/S0040-1951(03)00023-4.

Gutiérrez-Alonso, G., Fernández-Suárez, J., Jeffries, T.E., 2004. Age and setting of the of the Upper Neoproterozoic Narcea Antiform volcanic rocks (NW Iberia). Geogaceta 35, 79-82. Gutiérrez-Alonso, G., Fernández-Suárez, J., Collins, A.S., Abad, I., Nieto, F., 2005. Amazonian Mesoproterozoic basement in the core of the Ibero-Armorican Arc: ${ }^{40} \mathrm{Ar} /{ }^{39} \mathrm{Ar}$ detrital mica ages complement the zircon's tale. Geology 33, 637-640.

Gutiérrez-Alonso, G., Fernández-Suárez, J., Gutiérrez-Marco, J.C., Corfu, F., Murphy, J.B., Suárez, M., 2007. U-Pb depositional age for the upper Barrios Formation (Armorican Quartzite facies) in the Cantabrian zone of Iberia: implications for stratigraphic correlation and paleogeography. In: Linnemann, U., Nance, R.D., Kraft, P., Zulauf, G. (Eds.), The Evolution of the Rheic Ocean: From Avalonian-Cadomian Active Margin to Alleghenian-Variscan Collision. Geological Society of America Special Paper, vol. 423, pp. 287-296. doi:10.1130/2007.2423(13).

Gutiérrez-Marco, J.C., Robardet, M., Piçarra, J.M., 1998. Silurian stratigraphy and paleogeography of the Iberian Peninsula (Spain and Portugal). Temas Geológico Mineros ITGE 26, 610-617.

Gutiérrez-Marco, J.C., Aramburu, C., Arbizu, M., Bernardez, E., Hacar Rodríguez, M.P., MéndezBedia, I., Montesinos López, R., Rábano, I., Truyols, J., Villa, E., 1999. Revisión bioestratigráfica de las pizarras del Ordovícico Medio en el noroeste de España (zonas Cantábrica, Asturoccidentalleonesa y Centroibérica septentrional. Acta Geologica Hispanica 34, 3-87 (in Spanish).

Heinz, W., Loeschke, J., Vavra, G., 1985. Phreatomagmatic volcanism during the Ordovician of the Cantabrian Mountains. Geologische Rundschau 74, 623-639.

Jenner, G.A., Longerich, H.P., Jackson, S.E., Fryer, B.J., 1990. ICP-MS - a powerful tool for highprecision trace-element analysis in Earth sciences: evidence from analysis of selected U.S.G.S reference samples. Chemical Geology 83, 133-148.

Julivert, M., Marcos, A., Truyols, J., 1972. L'evolutión paléogéographique du nord-ouest de l'Espagne pendant l'Ordovicien-Silurien. Bulletin de la Societé Géologique et Minéralogique de Bretagne 4, 1-7 (in French).

Keppie, J.D., Nance, R.D., Murphy, J.B., Dostal, J., 2003. Tethyan, Mediterranean, and Pacific analogues for the Neoproterozoic-Paleozoic birth and development of peri-Gondwanan terranes and their transfer to Laurentia and Laurussia. Tectonophysics 365, 195-220.

Kerr, A., Jenner, G.A., Fryer, B.J., 1995. Sm-Nd isotopic geochemistry of Precambrian to Paleozoic granitoid suites and the deep-crustal structure of the southeast margin of the Newfoundland Appalachians. Canadian Journal of Earth Sciences 32, 224-245.

Lancelot, J.R., Allegret, A., Iglesias Ponce de León, M., 1985. Outline of upper Precambrian and coger Paleozoic evolution of the Iberian Peninsula according to U-Pb dating of zircon. Earth Planetary Science Letters 74, 325-337.

Loeschke, W.H.J., Zeidler, N., 1982. Early Paleozoic sills in the Cantabrian Mountains (Spain) and their geotectonic environment. Neues Jahrbuch fuÉr Geologie und PalaÉontologie. Monatshefte 7, 419-439.

López-Moro, F.J., Murciego, A., López-Plaza, M., 2007. Silurian/Ordovician asymmetrical sill-like bodies from La Codosera syncline, W Spain: A case of tholeiitic partial melts emplaced in a single magma pulse and derived from a metasomatized mantle source. Lithos 96, 567-590.

Marcos, A., Farias, P., 1999. La estructura de las láminas inferiores del Complejo de Cabo Ortegal y su autóctono en el área de Chantada (Galicia, NO de España). Trabajos de Geología, Universidad de Oviedo 21, 201-218 (in Spanish).

Marcos, A., Farias, P., Galán, G., Fernández, F.J., Llana-Fúnez, S., 2002. The tectonic framework of the Cabo Ortegal Complex: a slab of lower crust exhumed in the Variscan Orogen (NW Iberian Peninsula). In: Martínez Catalán, J.R., HatcherJr. Jr., R.D., Arenas, R., Díaz García, F. (Eds.), Variscan-Appalachian Dynamics: The Building of the Late Paleozoic Basement. Boulder, Colorado. Geological Society of America, Special Paper, vol. 364, pp. 143-162.

Marcos, A., Martínez Catalán, J.R., Gutiérrez-Marco, J.C., Pérez-Estaún, A., 2004. Estratigrafía y paleogeografía. In: Vera, J.A. (Ed.), Geología de España. S.G.E.-I.G.M. E., Madrid, pp. 49-52 (in Spanish).

Marquínez, J., 1984. La geologia del Area Esquistosa de Galicia Central (Cordillera Herciniana, NW de España). Memorias del Instituto Geológico y Minero 100, -1213 (in Spanish).

Martínez-Catalán, J.R., Hacar Rodríguez, M.P., Villar Alonso, M.P., Pérez-Estaún, A., González Lodeiro, F., 1992. Paleozoic extensional tectonics in the limit between the West AsturiasLeonese and the Central Iberian Zones of the Bariscan Fold-Belt in NW Spain. Geologische Rundschau 81, 545-560.

Martínez-Catalán, J.R., Arenas, R., Díaz García, F., Rubio Pascual, F.J., Abati, J., Marquinez, J., 1996. Variscan exhumation of a subducted Paleozoic continental margin: the basal units of the Ordenes Complex, Galicia, NW Spain. Tectonics 15, 106-121.
Martínez-Catalán, J.R., Arenas, R., Díaz García, F., Abati, J., 1997. Variscan accretionary complex of northwest Iberia: terrane correlation and succession of techtonother- mal events. Geology 25, 1103-1106.

Martínez-Catalán, J.R., Arenas, R., Díaz García, F., Abati, J., 1999. Allochthonous units in the Variscan belt of NW Iberia. Terranes and accretionary history. In: Sinha, A.K. (Ed.), Basement Tectonics, vol. 13. Kluwer Academic Publishers, pp. 65-84.

Martínez-Catalán, J.R., Arenas, R., Díez Balda, M.A., 2003. Large extensional structures developed during emplacement of a crystalline thrust sheet: the Mondoñedo nappe (NW Spain). Journal of Structural Geology 25, 1815-1839.

Martínez-Catalán, J.R., Arenas, R., Díaz García, F., Gómez-Barreiro, J., González Cuadra, P., Abati, J., Castiñeiras, P., Fernández-Suárez, J., Sánchez Martínez, S., Andonaegui, P., González Clavijo, E., Díez Montes, A., Rubio Pascual, F.J., Valle Aguado, B., 2007. Space and time in the tectonic evolution of the northwestern Iberian Massif. Implications for the comprehension of the Variscan belt. In: HatcherJr. Jr., R.D., Carlson, M.P., McBride, J.H., Martínez Catalán, J.R. (Eds.), 4-D Framework of Continental Crust. Geological Society Memoir, vol. 200, pp. 403423.

Matte, P., 2001. The Variscan collage and orogeny (480-290 Ma) and the tectonic definition of the Armorica microplate: a review. Terra Nova 13, 122-128.

McKerrow, W.S., Scotese, C.R. (Eds.), 1990. Palaeozoic Palaeogeography and Biogeo- graphy. Geological Society of London Memoir, vol. 12. 435p.

Miyashiro, A., 1974. Volcanic rock series in island arcs and active continental margin. American Journal of Science 274, 321-355.

Montero, P., Bea, F., Gonzalez-Lodiero, F., Talavera, C., Whitehouse, M.J., 2007. Zircon ages of the metavolcanic rocks and metagranites of the Ollo de Sapo domain in central Spain: implications for the Neoproterozoic to Early Paleozoic evolution of Iberia. Geological Magazine 144, 963-976.

Murphy, J.B., Dostal, J., 2007. Continental mafic magmatism of different ages in the same terrane: constraints on the evolution of an enriched mantle source. Geology 35, 335-338. Murphy, J.B., Strachan, R.A., Nance, R.D., Parker, K.D., Fowler, M.B., 2000. Proto-Avalonia: a 1.2 to 1.0 Ga tectonothermal Geology 28, 1071-1074. event and constraints for the evolution of Rodinia.

urphy, J.B., Eguiluz, L., Zulauf, G., 2002. Cadomian orogens, peri-Gondwanan correlatives and Laurentia-Baltica connections. Tectonophysics 352, 1-9.

Murphy, J.B., Gutierrez-Alonso, G., Nance, R.D., Fernandez-Suarez, J., Keppie, J.D., Quesada, C., Strachan, R.A., Dostal, J., 2006. Origin of the Rheic ocean: rifting along a Neoproterozoic suture? Geology 34, 325-328.

Murphy, J.B., Dustal, J., Keppie, J.D., 2008. Neoproterozoic-Early Devonian magmatism in the Antigonish Highlands, Avalon terrane, Nova Scotia: tracking the evolution of the mantle and crustal sources during the evolution of the Rheic Ocean. Tectonophysics 461, 181-201. doi:10.1016/j.tecto.2008.02.003

Patchett, P.J., Ruiz, J., 1989. Nd isotopes and the origin of the Grenville-age rocks in Texas: implications for Proterozoic evolution of the United States mid-continent region. Journal of Geology 97, 685-695.

Pearce, J.A., 1982. Trace element characteristics of lavas from destructive plate boundaries. In: Thorpe, R.S. (Ed.), Andesites. Wylie and Sons, pp. 525-548.

Pearce, J.A.,1996. Auser'sguidetobasaltic discriminationdiagrams. In: Wyman,D.A.(Ed.), Trace

Element Geochemistry of Volcanic Rocks: Applications for Massive Sulphide Exploration. Geological Association of Canada Short Course Notes, vol. 12, pp. 79-113.

Pearce, J.A., Norry, M.J., 1979. Petrogenetic implications of Ti, Zr, Y and Nb variations in volcanic rocks. Contributions to Mineralogy and Petrology 69, 33-47.

Pearce, J.A., Harris, N.B.W., Tindle, A.G., 1984. Traceelement discrimination diagrams for the tectonic interpretation of granitic rocks. Journal of Petrology 25, 956-983.

Pérez-Estaún, A., Bastida, F., Martínez-Catalán, J.R., Gutiérrez-Marco, J.C., Marcos, A., Pulgar, J.A., 1990. West Asturias-Leonese Zone: stratigraphy. In: Dallmeyer, R.D., Martínez-García, E. (Eds.), Pre-Mesozoic Geology of Iberia. Springer Verlag, Berlin, pp. 92-102.

Pin, C., Ortega Cuesta, L.A., Gil Ibarguchi, J.I., 1992. Mantle derived, early Paleozoic A- type metagranitoids from the NW Iberian massif: Nd isotope and trace-element constraints. Bulletin del la Societe Geologique de la France 163, 483-494.

Quesada, C., 1990. Precambrian terranes in the Iberian Variscan foldbelt. In: Strachan, R.A., Taylor, G.K. (Eds.), Avalonian and Cadomian Geology of the North Atlantic. Blackie and Son, Glasgow， pp. 109-133.

Quesada, C., Bellido, F., Dallmeyer, R.D., Gil Ibarguchi, J.I., Oliveira, J.T., Pérez Estaún, A., Ribeiro, A., Robardet, M., Silva, J.B., 1991. Terranes within the Iberian Massif: correlations with West African sequences. In: Dallmeyer, R.D., Lecorché, J.P. (Eds.), The West African Orogens and Circum-Atlantic Correlations. Springer-Verlag, Berlin, pp. 267-294.

Ribeiro, M.L., Floor, P., 1987. Magmatismo peralcalino no Maciço Hespérico: sua distribuçao e significado geodinámico. In: Bea, F., Carnicero, A., Gonzalo, J.C., López- Plaza, M., Rodríguez Alonso, M.D. (Eds.), Geología de los granitoides y rocas asociadas del Macizo Hespérico. Rueda, Madrid, pp. 211-221 (in Portuguese)

Ribeiro, A., Pereira, E., Dias, R., 1990. Structure in the NW of the Iberian Peninsula. In: Dallmeyer R.D., Martínez-García, E. (Eds.), Pre-Mesozoic Geology of Iberia. Springer Verlag, Berlin, pp. 221-236.

Robardet, M., 2002. Alternative approach to the Variscan Belt in Southwestern Europe: preorogenic paleobiogeographical constraints. In: Martínez-Catalán, J.R., Hatcher, R.D., Arenas, R., Díaz García, F. (Eds.), Variscan-Appalachian dynamics: the building of the late Paleozoic basement. Geological Society of America Special Paper, vol. 364, pp. 1-15.

Robardet, M., 2003. The Armorica microplate: fact or fiction? Critical review of the concept and contradictory paleobiogeographical data. Palaeogeography, Palaeocli- matology and Palaeoecology 195, 125-148

Robardet, M., Gutiérrez-Marco, J.C., 2004. The Ordovician, Silurian and Devonian sedimentary rocks of the Ossa-Morena Zone (SW Iberian Peninsula, Spain). Journal of Iberian Geology 30, 73-92.

Rodríguez, J., Cosca, M.A., Gil Ibarguchi, J.I., Dallmeyer, R.D., 2003. Strain partitioning and preservation of ${ }^{40} \mathrm{Ar} r^{39} \mathrm{Ar}$ ages during Variscan exhumation of a subducted crust (Malpica-Tui complex, NW Spain). Lithos 70, 111-139. 
Rodríguez Aller, J., 2005. Recristalización y deformación de litologías supracorticales sometidas a matamorfismo de alta presión (Complejo de Malpica-Tuy, NO del Macizo Ibérico). Laboratorio Xeolóxico de Laxe. . Serie Nova Terra, vol. 29. A Coruña. 572 pp. (in Spanish).

Samson, S.D., D'Lemos, R.S., 1998. U-Pb geochronology and Sm-Nd isotopic composi- tion of Proterozoic gneises, Channel Islands, UK. Journal of the Geological Society, London 155, 609-618.

Sánchez-García, T., Bellido, F., Quesada, C., 2003. Geodynamic setting and geochemical signatures of Cambrian-Ordovician rift-related igneous rocks (Ossa-Morena Zone, SW Iberia). Tectonophvsics 365, 233-255.

Sánchez-Martínez, S., Jeffries, T., Arenas, R., Fernández-Suárez, J., García-Sánchez, R., 2006. A pre-Rodinian ophiolite involved in the Variscan suture of Galicia (Cabo Ortegal Complex, NW Spain). Journal of the Geological Society 163, 737-740.

Santos Zalduegui, J.F., Schärer, U., Gil Ibarguchi, J.I., 1995. Isotope constraints on the age and origin of magmatism and metamorphism in the Malpica-Tuy allochthon, Galicia, NW-Spain. Chemical Geology 121, 91-103.

Stampfli, G.M., Borel, G.D., 2002. A plate tectonic model for the Paleozoic and Mesozoic constrained by dynamic plate boundaries and restored synthetic oceanic isochrones. Earth and Planetary Science Letters 196, 17-33.

Stampfli, G.M., von Raumer, J.F., Borel, G.D., 2002. Paleozoic evolution of pre-Variscan terranes: from Gondwana to the Variscan collision. Geological Society of America Special Paper 364, 263-280.

Steiger, R.H., Jäger, E.,1977. Subcommission on Geochronology: convention on theuse of decay constants in geo- and cosmochronology. Earth and Planetary Science Letters 36, 359-362. Suárez, O., Gallastegui, G., Cuesta, A., Corretgé, L.G., Tarrío, L., 1993. Geoquímica de las rocas volcánicas del Cabo Peñas

(Zona Cantábrica): V Congreso de Geoquímica de España. Actas del Congreso. ISBN: 84-77901993, (in Spanish).

156-2, pp. 42-47. Soria, 21-24 Sept.,

Sun, S.-S., McDonough, W.F., 1989. Chemical and isotopic systematics of oceanic basalts: implications for mantle composition and processes. In: Saunders, A.D., Norry, M.J. (Eds.), Magmatism in the Oceanic Basins. Geological Society of London Special Publication, vol. 42, pp. 313-345.

Tatsumi, Y., 2005. The subduction factory, how it operates in the evolving Earth. GSA Today 15 (7), 4-10.

Taylor, S.R., McLennan, S.M., 1985. The Continental Crust: its Composition and Evolution Blackwell Scientific Publications, Oxford.
Truyols, J., Aramburu, C., Arbizu, M., Gutiérrez-Marco, J.C., García-Ramos, J.C., Méndez- Bedia, I., Rábano, I., Villa, E., 1996. La Formación vulcanosedimentaria del Castro (Ordovícico-Silúrico) en el Cabo Peñas (Zona Cantábrica, NO de España). Geogaceta 20, 15-18 (in Spanish).

Valverde-Vaquero, P., Dunning, G.R., 2000. New U-Pb ages for Early Ordovician magmatism in Central Spain. Journal of the Geological Society, London 157,15-26. ValverdeVaquero, P., Marcos, A., Farias, P., Gallastegui, G., 2005. U-Pb dating of Ordovician felsic volcanism in the Schistose Domain of the Galicia-Trás-os-Montes Zone near Cabo Ortegal (NW Spain). Geologica Acta 3 (1), 27-37.

van Staal, C.R., Dewey, J.F., Mac Niocaill, C., McKerrow, W.S., 1998. The Cambrian- Silurian tectonic evolution of the Northern Appalachians and British Caledonides: history of a complex, west and southwest Pacific-type segment of Iapetus. In: Blundell, D., Scott, A.C. (Eds.), Lyell: The Past is the Key to the Present. Geological Society of London Special Publication, vol. 143, pp. 199-242.

Vera, J.A. (Ed.), 2004. Geología de España. S.G.E.-I.G.M.E., Madrid. 890 pp. (in Spanish). Villa, L., Corretgé, L.G., Arias, D., Suárez, O., 2004. Los depósitos volcanoclásticos sin- eruptivos de LagoOviedo 24, 185-205 (in Spanish).

von Raumer, J., Stampfli, G., Borel, G., Bussy, F., 2002. Organization of pre-Variscan basement areas at the north-Gondwanan margin. International Journal of Earth Sciences 91, 32-52.

Weil, A.B., Van der Voo, R., van der Pluijm, B., 2001. New paleomagnetic data from the southern Cantabria-Asturias Arc, northern Spain: implications for true oroclinal rotation and the final amalgamation of Pangea. Geology 29, 991-994.

Winchester,J.A., Floyd,P.A.,1977.Geochemical discrimination of differentmagmaseries and their differentiation products using immobile elements. Chemical Geology 20, 325-343. Wood, D.A., Joron, J.-L., Treuil, M., 1979. A re-appraisal of the use of trace elements to classify and discriminate between magma series erupted in different tectonic settings. Earth and Planetary Science Letters 45, 326-336.

Zeck, H.P., Whitehouse, M.J., Ugidos, J.M., 2007. $496 \pm 3$ Ma zircon ion microprobe age for preHercynian granite, Central Iberian Zone, NE Portugal (earlier claimed $618 \pm 9$ ). Geological Magazine 144, 21-31. 